\title{
Tarihi Kahramanların Değerler Ĕgitiminde Rol Model Olarak Kullanılmasına İlişkin Ortaokul Öğrencilerinin Algıları
}

\section{Melike FAIZ*, Emine KARASU AVCI**}

Öz: Tarihi kahramanlar hem kişilikleriyle hem de toplumsal hayata olan katkılarıyla insanlık tarihinde önemli yer edinmiş şahsiyetler olarak tanımlanabilir. Bilim insanları, sanatçılar, politikacılar ve toplum liderleri önemli tarihi kahramanlardır. Tarihi süreçte toplumlar ihtiyaç duyduğu insan modelini oluşturmak için bu tarihi kahramanlardan faydalanmışlardır. Tarihi kahramanlar değer öğretiminin somutlaştırılmasında etkilidir. Eğitim sistemlerinde değerlerin aktarılmasında tarihi kahramanların önemli bir yeri olduğu söylenebilir. Tarihi kahramanlar yoluyla değerler öğrencilere somutlaştırılarak kazandırılabilir. Bu araştırmada 5., 6. ve 7.sınıf öğrencilerinin Sosyal Bilgiler Öğretim Programı'nda yer alan değerler ile hangi tarihi kahramanları ilişkilendirdikleri tespit edilmiştir. Araştırma nitel modelde tasarlanmış olup bir durum çalışmasıdır. Öğrenciler Sosyal Bilgiler derslerinde hem tarihi kahramanları hem de değerleri öğrenmektedirler. Araştırma 2017-2018 eğitim-öğretim yılı bahar yarıyılında gerçekleştirilmiştir. Araştırmada Sosyal Bilgiler dersini alan 5., 6. ve 7.sınıf öğrencileri tercih edildiği için araştırmanın örneklem türü uygun örnekleme yöntemidir. Bu doğrultuda 5., 6. ve 7.sınıf öğrencilerine Sosyal Bilgiler Öğretim Programı'ndaki değerleri tarihi kahramanlar ile ilişkilendirmeleri istenmiştir. Elde edilen veriler betimsel analizi yolu ile çözümlenmiştir. Buna göre 5., 6. ve 7.sınıf öğrencileri değerler ile en fazla Hz. Muhammed (s.a.v.) ile Mustafa Kemal Atatürk'ü ilişkilendirmişlerdir. Ayrıca öğrencilerin değerleri hem yerel hem de evrensel tarihi kahramanlarla ilişkilendirdikleri de görülmektedir.

Anahtar kelimeler: Tarihi kahramanlar, değerler, Sosyal Bilgiler.

\section{Perceptions of Secondary School Students on the Use of Historical Heroes as Role Model in Values Education}

*Dr. Öğr. Üyesi, Kastamonu Üniversitesi, Eğitim Fakültesi, Sosyal Bilimler Bölümü, Email:mfaiz@kastamonu.edu.tr Orcid No: 0000-0001-8070-6086.

** Dr. Öğr. Üyesi, Kastamonu Üniversitesi, Eğitim Fakültesi, Sosyal Bilimler Bölümü, Email:eavci@kastamonu.edu.tr Orcid No: 0000-0002-3135-2557.

Gönderim:21.12.2018 Kabul:18.03.2019 Kayın:05.04.2019


Abstract: Historical heroes can be described as personalities who have taken an important place in history with their personalities as well as their contribution to social life. Scientists, artists, politicians and community leaders are important historical heroes. Historically, societies have benefited from these historical heroes to create the human model they need. Historical heroes are effective in embodying value education. It can be said that historical heroes have an important role in transferring values in education systems. Through historical heroes, values can be made concrete by students. In this research, it is aimed to determine which historical heroes relate to the values of the 5th, 6th and 7th grade students in the Social Studies Curriculum. The research was designed in a qualitative model and it is a case study. Students learn both historical heroes and values in social studies classes. The research was carried out in the spring semester of 2017-2018 academic year. Since the 5th, 6th and 7th grade students who took the Social Studies course were preferred in the survey, the sample of the research was chosen as convenience sampling type. In this direction, students in grades 5, 6 and 7 are required to associate the values in the Social Studies Curriculum with historical heroes. The obtained data are analyzed by descriptive analysis and divided into several categories. According to this, students in 5th, 6th and 7th grades have the highest values with Hz. Muhammad (saas) and Mustafa Kemal Atatürk. Other results of the research will be included in the full text.

Key words: Historical heroes, Values, Social Studies.

\section{Giriş}

Son yüzyılda birçok ülkede değerler eğitimi önemli bir olgu haline gelmiştir. Bu nedenle günümüzde neredeyse her ülkede değerlerin nasıl kazandırılacağı sorgulanmaya başlanmıştır. Kymlicka (2004) değerlerin kaynaklarının aile, akran grupları, sivil toplum örgütleri, kitle iletişim araçları olarak belirtmektedir. Değerler eğitimine yönelik ilginin artmasıyla teorisyenler ve araştırmacılar değer eğitimine ilişkin çeşitli yöntem ve stratejiler geliştirmişlerdir. $\mathrm{Bu}$ yöntem ve stratejilerden birisi olan gözlem yoluyla öğrenme modeli, rol model olmanın asıl unsurunu oluşturmakta ve uzun zamandır değerler eğitiminde önemli bir yöntem olarak kabul edilmektedir. Birçok çalışmada, bilişsel etkinlik, didaktik veya anlatı yöntemlerinin değerler eğitiminde tek başına 
yetersiz olduğunu göstermektedir. Eğitim-öğretim süreci düşünüldüğünde öğrencilerin rol model aldığg kişilerin başında öğretmenler gelmektedir. Öğretmenler özellikle küçük yaşlardaki öğrencilerin günlük hayatlarının kahramanlarıdır. Dolayısıyla öğretmenlerin söz ve davranışlarında özenli olmaları gerekir (Yazıcı ve Aslan, 2011). Değerler eğitiminde duyuşsal ve davranışsal boyut bilişsel boyuta göre daha ön plandadır. Öğretmenlerin değerleri öğretirken bunu davranışlarına yansıtmaları öğrencilerin davranışlarını şekillendirmede büyük önem taşımaktadır (Titus, 1994). Her ne kadar öğretmenler iyi rol model olsalar da çocukların ilerleyen dönemlerde kendilerine başka kahramanlar da buldukları bilinmektedir (Gibbon, 2002). Lakshimi (2009) çocukların daha çok film yıldızlarını ya da çok para kazanan başarılı kişileri kahraman olarak seçtiklerini belirtmektedir. Fakat çocukların seçtikleri bu kahramanların olumsuz özellikleri de bulunabilir. Çocuklar bu olumsuz özellikleri rol model edinerek istenmeyen davranışlar ve tutumlar sergileyebilirler. $\mathrm{Bu}$ ve benzeri durumlar toplumların eğitim programları aracılığıyla önlemler alınmasını gerekli hale getirmektedir. $\mathrm{Bu}$ nedenle eğitim-öğretim programlarında okul öncesi eğitim döneminden başlayarak öğrencilere rol model olabilecek kahramanlar sunularak değerler eğitiminin sağlanması bir gereklilik halini almaktadır.

Kahramanların değerler eğitiminde rolü ve öneminden bahsetmeden önce kahraman kavramını açıklamak yerinde olacaktır. Elban (2018) kahramanı toplumların geçmişinde önemli yer etmiş, düşünce ve eylemleri ile toplumlara yön vermiş kişiler olarak belirtmektedir. Tarihsel zaman sürecinde bağımsızlık ve özgürlük mücadelesi veren milletlerin bir kahramanlarının bulundukları söylenebilir. Ancak günümüzde kahraman kavramının kapsamı genişleyerek bilim, sanat, teknoloji, siyaset, askeri, yönetim, edebiyat gibi alanlarının da kendine özgü kahramanları toplumda kabul görmeye başlamıştır (Yazıcı ve Aslan, 2011). Bir başka görüşe göre de kahraman; zaman ve mekân olarak sınırlarını aşan sıradan olmayan kişilerdir (Aslan, 2009). Kahramanlar toplumların ortak ata anlatılarından yola çıkarak nesilden nesile aktarılan insanların düşüncelerinde bugün dahi canlı olan kişilerdir (Elban, 2018). Hem ait oldukları toplumun değerlerini hem de evrensel değerleri temsil eden kişilerdir (Yazıcı ve Aslan, 2011). 
Eğitim sistemlerinde kahramanlardan yararlanma yaklaşımı ile toplumsal yaşantıdaki çözülmeler, şiddet ve siyasal istikrarsızlık gibi problemlerin üstesinden gelinebilir (Yazıcı ve Aslan, 2011). Kahramanların yaşamış tarihi kişiler olmaları öğrencilerin hem duyuşsal hem de bilişsel gelişimlerine katkı sağlayacaktır. Tarihi kahramanların hayatları değerlerin aktarımında bir araçtır (Demircioğlu ve Tokdemir, 2008). Tarihi kahramanların aynı zamanda bireyler için rol model olma gibi bir işlevi de vardır. Bireyler tarihi kahramanları rol model alarak çeşitli kazanımlar elde edebilirler.

Bandura (1977)’ya göre bireyler modelleri taklit ederek ve davranışları gözlemleyerek öğrenirler. Ona göre, toplumlardaki yüksek statülü insanların en çok taklit edilen modeller olmaları gözlemleyerek ve rol model alarak öğrenmenin bir sonucu olarak değerlendirilebilir. Bandura'nın sosyal öğrenme kuramında bireyler yeni bilişsel beceri ve davranışları öğrenilebilirler. $\mathrm{Bu}$ öğrendiklerini güçlendirebilir veya söndürebilirler. Modelleri gözlemleyerek sosyal motivasyon sağlayacaklarından çevrenin ve nesnelerin nasıl kullanılacağı ve duygusal tepkilerin nasıl ortaya konulacağını kavrayacaklardır. Değerlerin aktarımı için de bu durumun geçerli olduğu söylenebilir. Dönmez (2006) kazandırılmak istenilen değerlerin kalıcılığını artırabilmesi için değerlerin doğrudan soyut değerler şeklinde değil; topluma mal olmuş ve önde gelen kişiler ya da en somut kahramanlar yoluyla verilmesi gerektiğini belirtir. Doğanay (2006) ise çocukların kelimeleri ve eylemleri öğrenirken iyi kişisel özellikleri olan uygun modellere ihtiyaçları olduğundan bahseder. Bu bağlamda değerlerin öğretiminin, tarihi kahramanlara başvurularak gerçekleştirilmesinin önemi anlaşılabilir. Birey, iyi ve doğru olanı yapmak için kendi eylemlerini kontrol edebildiğini öğrendiğinde kahramanları taklit etmeye başlar. Tarihi kahramanlar aracılığıyla bireyler disiplin, özdenetim, saygı gibi değerleri kazanırlar (Hall, 2003). Kahramanları gözlemleyen bireylerde ait olma ve benimseme eğilimleri görülür. Ahlaki, politik ve kişisel olarak kahramanlar bireylere hayatlarından örnekler yoluyla ilham verebilirler (Sanchez, 1998a). Yazıcı ve Aslan (2011) değerler eğitiminde tarihi kahramanlardan faydalanılmasını değerlerin duygusal yanının olmasına ve bu değerlerin kahramanlar kullanılarak kazandırılmasının daha etkili olduğuna bağlamaktadırlar. Ayrıca değerler ve kahramanlar arasında kavramsal bir ilişki olduğunu da belirtirler. Gibbon (2002) değerler eğitiminde kahramanların kullanılmasının çocukların içindeki derin ve güçlü 
dürtüleri ortaya çıkardığını belirtir. Kahramanların özentileri ve idealize etme ihtiyacını karşılama gibi bir rolü olduğundan bahseder. Fraenkel (1968)'e göre de bireylerin empati kurabilmelerinde kahraman hikayeleri önem taşımaktadır. Bireyler kendilerini kahramanların yerine koyarak değerleri kazanabilirler. Bu bağlamda okullarda değerlerin aktarımında kahramanların da rolü anlaşılmaktadır. Öğrencilerin empati kurabilmeleri için kahraman hikayelerinin kullanması gereklidir. Kadın ve erkek tarihi kahramanlarla ilgili verilecek hikâyeler öğrencilerin dikkatini ve ilgisini çekecektir (Sanchez, 1998b).

Değerler eğitiminde tarihi kahramanların yaşam öykülerinin kullanılmasında dikkat edilecek hususlar bulunmaktadır. Bunlardan birisi kahramanın bütün özelliklerinin verilmesi yönündedir. İyi kahramanlar, genellikle karmaşık bireyler olarak resmedilir. Bu yüzden bu kahramanların hem olumlu hem de olumsuz özellikleri ortaya konulmalıdır. Ayrıca birçok ana karakter güçlü rol modellerdir. Çünkü kendi olumsuz özelliklerinin veya zayıflıklarının üstesinden gelmişlerdir. Çocuklarla bu kahramanları tartışmak, karakter özelliklerinin başkalarında nasıl ifade edildiğini ve çocukların kendi içinde olumlu karakter özelliklerini nasıl geliştirebileceklerini düşünmek için sayısız firsat sunmaktadır. Bunun yanında kahramanlar tüm dünyadan örneklerle verilmelidir. Böylece çocuklar dünyadaki toplumsal beklenti ve değerlerle ilgili bir anlayış geliştirirler. Özel bir bölgede veya devirde yaşamanın, kadın ya da erkek olmanın ne anlama geldiğini kavrayabilirler (Singh ve Lu, 2003).

Türk milletinin fertlerini bilişsel ve akademik yönden eğitmek kadar milli ve evrensel değerleri kazandırmak Türk Milli Eğitimi’nin temel görevidir. Milli, manevi ve ahlaki değerlerimizin yanı sıra evrensel değerleri temsil yeterliliğine sahip, iyi seçilmiş kahramanların eğitimde kullanılması çocukların bu kahramanlarla özdeşim kurmasını, onları model almasını ve kendi kahramanı yapmasını sağlayabilir. Sosyal Bilgiler derslerinin içeriğini oluşturan tarih konularını, tarihteki kahramanların hikâyeleriyle destekleyerek; güncel, bilimsel gelişmelerle ve toplumsal olaylarla ilgili konuları, o alandaki yerli ve evrensel günümüz kahramanlarını kullanarak öğretmek, bu değerlerin öğrenciye kazandırılmasında büyük kolaylıklar sağlayabilir.

Türkiye'deki değerler eğitimi ile ilgili literatür incelendiğinde öğrencilerin değerleri kazanma düzeylerini (Beldağ, 2012); Sosyal Bilgiler Dersi Öğretim Programı 
uygulama kılavuzunda yer alan etkinliklerin değer eğitimi yaklaşımları açısından durumunu (Yiğittir ve Kaymakc1, 2012); ders kitaplarındaki değerlere karşı tutumları (Tahiroğlu, 2011); ilköğretim beşinci sınıf Sosyal Bilgiler dersinde değerler eğitiminin nasıl gerçekleştiğini (Çengelci, 2010); öğretmenlerin değer yönelimlerini (Gedik, 2010); Sosyal Bilgiler Dersi Öğretim Programı'nda yer alan değerlerin kazandırılması sürecine ilişkin öğretmen görüşlerini (Kılıç-Şahin, 2010); öğretmenlerin değer öğretiminde kullandıkları yöntemleri (Akbaş, 2009); öğretmen adaylarının Sosyal Bilgiler Dersi Öğretim Programı'nda yer almasını öngördükleri değerler ve hangi değerlerin neden öğretileceğine ilişkin görüşlerini (Tay, 2009; Evrim ve Kafadar, 2004); sınıf öğretmenlerinin ve tarih öğretmenlerinin değer eğitimine ilişkin görüşlerini (Yıldırım, 2009; Tokdemir, 2007); Eğitim Fakültesi Sınıf Öğretmenliği ve Sosyal Bilgiler Öğretmenliği öğrencilerinin değer öğretimi hakkındaki görüşlerini (Fidan, 2009); geleneksel ve demokratik değerlere yönelik öğrenci tutumlarını (Ulusoy, 2007); değer eğitimine yönelik genel açıklamaları (Yazıcı, 2006); yeni ilköğretim sosyal bilgiler dersi programında insan hakları ve değer eğitiminin yer alış biçimini (Sarı, 2005); değerler eğitiminde tarihi kahramanların kullanılmasını (Yazıcı ve Aslan, 2011; Faiz ve Yazıcı, 2018); Türk Milli Eğitim Sisteminin duyuşsal amaçlarının ilköğretim II. kademede gerçekleşme derecesinin değerlendirilmesine (Akbaş, 2004) yönelik yapılan çalışmalar mevcuttur.

Yabancı alan yazın incelendiğinde ise farklı eğitim düzeylerinde görev yapan öğretmenlerin değerlerini kültürler arası karşılaştırmalar şeklinde inceleyen ve öğretmenlerin, ahlak eğitimindeki görevlerini belirlemeye yönelik araştırmalara (Leblanc, 2007; Coombs-Richardson ve Tolson, 2005; Veugelers ve Kat, 2003); ergenlerin ve gençlerin değerlerini çeşitli değişkenler çerçevesinde araştıran araştırmalara (Owens, 2008; Silfver, 2007; Miethe, 2001; Bohning, Hodson, Foote, McGee ve Young,1998); değer öğretimi, karakter eğitimi ve karş1laşılan sorunlara ve hizmet öncesi öğretmen eğitiminde değer eğitimine yönelik araştırmalara (Thornberg, 2008; Lewis, 2007; Chandler, 2005; Ledford, 2005; Moore, 2005; Willemse, Lunenberg ve Korthagen, 2005; Revell, 2002; Veugelers, 2000) rastlanılmaktadır. Literatürdeki bu çalışmalar, bu çalışmanın amacı ve kapsamı doğrultusunda elde edilen çalışmalardır. Literatürde yapılan çalışmalar yukarıdaki gibi özetlenmiştir. 
Bu araştırmada da ortaokul öğrencilerinin Sosyal Bilgiler Öğretim Programı’nda yer alan değerlerle tarihi kahramanları ilişkilendirmeleri istenmiştir. Daha önceden de belirtildiği üzere değer eğitimin etkili olduğu yaklaşımlardan birisi olan rol model alarak öğrenme yaklaşımı olduğu düşünüldüğünde öğrencilerin rol modelleri tespit edilecektir. Böylece derslerde bu kahramanlara daha fazla yer verilmesi sağlanabilecektir. Bu da değerler eğitimi daha etkili hale getirebilir.

\section{Yöntem}

\section{Araştırmanın Modeli}

Araştırma durum çalışması şeklinde tasarlanmıştır. Durum çalışması, araştırmacı/araştırmacıların bir programı, etkinliği, süreci veya kişiyi derinlemesine incelenmesidir (Creswell, 2014). Bu araştırmada 5., 6. ve 7.sınıf öğrencilerinin Sosyal Bilgiler Öğretim Programı'nda yer alan değerler ile hangi tarihi kahramanları ilişkilendirdikleri tespit edilmek istendiği için bu yöntem tercih edilmiştir.

\section{Çalıșma Grubu}

$\mathrm{Bu}$ araştırmanın çalışma grubunu, 2017-2018 eğitim-öğretim y1lı bahar yarıyılında bir devlet okulunda öğrenim görmekte olan 5., 6.ve 7.sınıf öğrencileri oluşturmaktadır. 5.sınıf öğrencileri 31, 6.sınıf öğrencileri 19 ve 7.sınıf öğrencileri 24 kişiden oluşmaktadır. Araştırmaya toplamda 74 ortaokul öğrencisi katılmıştır. Çalışma grubu seçilirken rastgele olmayan örnekleme tekniklerinden biri olan uygun örnekleme yöntemi kullanılmıştır. Uygun örnekleme, kolaylıkla ulaşılabilen kişilerin örneklem grubuna dâhil edilmesi durumu olarak açıklanmaktadır (Creswell, 2014).

\section{Verilerin Toplanması ve Analizi}

$\mathrm{Bu}$ araştırmada veri toplama aracı olarak Sosyal Bilgiler Öğretim Programı'nda yer alan 18 değere ilişkin 5., 6. ve 7.sınıf öğrencilerinin tarihi kahramanlarla ilişsilendirmeleri için anketten faydalanılmıştır. Anket, araştırmaya dâhil edilen katılımcıların duygu, düşünce, tutum, inanç ve algıları hakkında bilgi edinmek amacıyla kullanılan veri toplama aracıdır (Creswell, 2014). 5., 6.ve 7.sınıf öğrencilerine Sosyal Bilgiler Öğretim Programı'nda yer alan değerleri tarihi kahramanlarla ilişkilendirebilmeleri için bir ders saati süre (40 dk.) tanınmıştır. Araştırmada veri toplama aracı, aşağıda verilen örnek değer ve tarihi kahraman ilişkilendirmesi şeklinde düzenlenmiştir: “Adalet” değerini ilişkilendirdiğiniz tarihi kahramanları yazınız. 
1.

(Lütfen başka tarihi kahramanlarla da ilişkilendiriyorsanız yazınız.)

Araştırma kapsamında elde edilen veriler nitel araştırmalarda sıklıkla tercih edilen betimsel analiz yönteminden çözümlenmiştir. Betimsel analiz, verilerin önceden belirlenmiş temalara, gözlem ve görüşme süreçlerinde kullanılan sorulara göre düzenlenmesi durumudur (Yıldırım ve Şimşek, 2016). Elde edilen veriler tabloya aktarılmıştır. Öğrencilerin değerleri ilişkilendirdikleri tarihi kahramanlar her bir sınıf düzeyi için farklı farklı sınıflandırılmıştır. Araştırmada ankete geçerli cevap veren toplam 74 (5., 6. ve 7.sınıf) öğrenci vardır. Anketi doldurmayıp boş bırakan ve araştırmanın soruları doğrultusunda cevap vermeyen öğrencilerden elde edilen veriler araştırmaya dâhil edilmemiştir.

\section{Çalışmanın Güvenirlik ve Geçerliğinin Sağlanması}

Güvenirlik, araştırmacı ya da araştırmacıların araştırma problemine ilişkin benzer sonuçları elde etmesi ve araştırma sonuçlarının gerçeği yansıtıp yansıtmaması olarak açıklanmaktadır (Ekiz, 2013). Bu araştırmada güvenirlik, araştırmacıların elde edilen verileri birbirlerinden bağımsız olarak analiz etmesi ve sonuçlarının karşılaştırılarak ortak bir sonuca varılması ile elde edilmiştir. Araştırmanın güvenirliği için Miles ve Huberman (1994)'ın belirttiği formül uygulanmıştır. Uzlaşma Yüzdesi $(P)=$ Görüş Birliği $(\mathrm{Na}) /$ Görüş Ayrılığı $(\mathrm{Nd})$ x 100 formülü kullanılarak güvenirlik hesaplanmıştır. Buna göre Uzlaşma Yüzdesi $(\mathrm{P})=100$ olarak bulunmuştur. Bunun sebebi verilerin değerler bağlamında bir tarihi kahraman ile ilişkilendirilmesi ve bu bulgunun iki araştırmacı tarafından da farklı yorumlanma ihtimalinin olmaması durumudur. Ayrıca araştırmada verilerin analiz sürecinin ayrıntılı bir şekilde açıklanması, elde edilen verilerin bulgular kısmında sistemli ve aşamalı olarak sunulması ile araştırmanının geçerliği sağlanmaya çalışılmıştır.

\section{Bulgular ve Yorum}

Araştırmanın bu bölümünde araştırmadan elde edilen bulgulara tablolar halinde yer verilerek yorumlanmıştır.

Tablo 1. Adalet Değerine İlişkin Ortaokul Öğrencilerin Eşleştirmeleri

\begin{tabular}{llllll}
\hline 5.sınıf & f & 6.sınıf & f & 7.sınıf & f \\
\hline Mustafa Kemal Atatürk & 15 & Mustafa Kemal Atatürk & 18 & Hz. Ömer & 11 \\
Hz. Ömer & 4 & Vecihi Hürkuş & 1 & Mustafa Kemal Atatürk & 9 \\
Recep Tayyip Erdoğan & 3 & & & Fatih Sultan Mehmet & 3 \\
Kanuni Sultan Süleyman & 2 & & & & \\
Hz. Muhammed & 2 & & &
\end{tabular}


Mehmet Akif Ersoy 1

Kevin Parker 1

Ömer Halisdemir 1

Adalet Bakanı 1

Lionel Messi 1

Toplam 31

19

Tablo 1 incelendiğinde adalet değerine ilişkin olarak 5.sınıf öğrencilerinin 10; 6.sınıf öğrencilerinin 2 ve 7.sınıf öğrencilerinin 4 farklı tarihi kahraman belirttikleri görülmektedir. 5.sınıf öğrencileri adalet değerini en fazla sırasıyla "Mustafa Kemal Atatürk” ( $f=15)$, “Hz. Ömer” $(f=18)$ ve “Recep Tayyip Erdoğan”( $f=3) ; 6 . s ı n ı f$ öğrencileri "Mustafa Kemal Atatürk” ü (f=18) ve 7.sınıf öğrencileri “Hz. Ömer” (f=11); 7.sınıf öğrencileri "Mustafa Kemal Atatürk" (f=9) ve "Fatih Sultan Mehmet" ( $\mathrm{f}=3$ ) gibi tarihi kahramanlar ile eşleştirmişlerdir. Bu üç düzey öğrenci grubunun adalet değerine ilişkin ortak olarak belirttikleri tarihi kahramanın "Mustafa Kemal Atatürk" olduğu görülmektedir. Ayrıca 5.ve 7.sınıf öğrencilerinin ortak olarak belirttiği bir diğer tarihi kahramanın da "Hz. Ömer” olduğu görülmektedir. 5.sınıf öğrencilerinden biri “Ömer Halisdemir"i adalet değeri ile ilişkilendirmiştir. Ayrıca her üç sınıf düzeyinde bulunan öğrenciler adalet değerini ağırlıklı olarak dini, siyasi ve askeri anlamda tarihi kahramanlarla ilişkilendirmişlerdir. Bu alanlara ilaveten edebiyat, müzik, spor, pilot gibi mesleki alanlarda görev yapanları belirtmişlerdir.

Tablo 2. Aile Birliğine Önem Verme Değerine İlişkin Ortaokul Öğrencilerinin Eşleştirmeleri

\begin{tabular}{llllll}
\hline 5.sınıf & f & 6.sınıf & f & 7.sınıf & f \\
\hline Hz. Muhammed & 16 & Hz. Muhammed & 9 & Hz. Muhammed & 21 \\
Mustafa Kemal Atatürk & 8 & Mustafa Kemal Atatürk & 3 & Mustafa Kemal Atatürk & 3 \\
Mehmet Akif Ersoy & 3 & Hz. Ömer & 3 & & \\
Mevlana & 2 & Hz. Âdem & 2 & \\
Hz. Yusuf & 1 & Hz. Osman & 1 & \\
Enes Batur & 1 & Şerife Bacı & 1 & \\
Toplam & 31 & & 19 & \\
\hline
\end{tabular}

Tablo 2 incelendiğinde aile birliğine önem verme değerine ilişkin olarak 5.sınıf öğrencileri 6; 6.sınıf öğrencileri 6 ve 7.sınıf öğrencileri 2 farklı tarihi kahraman belirtmişlerdir. 5.sınıf öğrencileri aile birliğine önem verme değerini en fazla sırasıyla "Hz. Muhammed" (f=16), "Mustafa Kemal Atatürk" (f=8) ve "Mehmet Akif Ersoy" $(f=3)$; 7.sınıf öğrencileri "Hz. Muhammed” (f=9), "Mustafa Kemal Atatürk" (f=3) ve "Hz. Ömer" ( $\mathrm{f}=3)$; 7.sınıf öğrencileri ise "Hz. Muhammed" ( $\mathrm{f}=21)$ ve "Mustafa Kemal Atatürk” (f=3) gibi tarihi kahramanlar ile eşleştirmişlerdir. Öğrencilerin aile birliğine önem verme değerine ilişkin ortak belirttikleri tarihi kahramanın "Hz. Muhammed" ve 
"Mustafa Kemal Atatürk” olduğu görülmektedir. Öğrenciler genel olarak aile birliğine önem verme değerini dini, askeri, siyasi ve edebiyat alanlarındaki tarihi kahramanlarla ilişkilendirmişlerdir. Buna ilaveten 5.sınıf öğrencilerinden biri “Enes Batur” gibi günümüz sosyal medya fenomenini de tarihi kahraman olarak algıladığı görülmektedir. 6.sınıf öğrencilerinden biri de araştırmanın yapıldığı şehirde önemli bir yerel tarihi kahraman olan “Şerife Bacı”yı bu değer ile ilişkilendirmiştir.

Tablo 3. Bağımsızlık Değerine İlişkin Ortaokul Öğrencilerinin Eşleştirmeleri

\begin{tabular}{llllll}
\hline 5.sınıf & f & 6.sınıf & f & 7.sınıf & f \\
\hline Mustafa Kemal Atatürk & 18 & Mustafa Kemal Atatürk & 12 & Mustafa Kemal Atatürk & 17 \\
Serife Bacı & 4 & Metehan & 4 & I. Murat & 3 \\
Ertuğrul Gazi & 2 & Fatih Sultan Mehmet & 2 & Mehmet Akif Ersoy & 3 \\
Mevlana & 2 & Hz. Muhammed & 1 & II. Sultan Selim & 1 \\
Amir Khan & 1 & & & & \\
Ruhi Çenet & 1 & & & & \\
Adolf Hitler & 1 & & & & \\
Yunus Emre & 1 & & & & \\
Mehmet Akif Ersoy & 1 & & 19 & \\
Toplam & 31 & & & \\
\hline
\end{tabular}

5.sınıf öğrencileri bağımsızlık değeri ile ilgili "Mustafa Kemal Atatürk" ( $f=18)$ ve "Şerife Bacı" (f=4); 6.sınıf öğrencileri "Mustafa Kemal Atatürk" (f=12) ve "Metehan" $(\mathrm{f}=4)$; 7.sınıf öğrencileri ise "Mustafa Kemal Atatürk" ( $f=17)$, "I.Murat” ( $f=3$ ) ve "Mehmet Akif Ersoy"u (f=3) ilişkilendirmişlerdir. Bağımsızlık değeri ile ilgili 5.sınıf öğrencileri 9; 6.sınıf öğrencileri 4 ve 7.sınıf öğrencilerinin 4 tarihi kahraman belirtmişlerdir. Tüm öğrencilerin en çok üzerinde durduğu tarihi kahramanın "Mustafa Kemal Atatürk" olduğu görülmektedir. Bununla birlikte öğrencilerin ortak olarak "Mehmet Akif Ersoy”u da belirttikleri görülmektedir. Öğrenciler bağımsızlık değeri ile ilgili belirttikleri tarihi kahramanların daha çok askeri, siyasi, dini ve edebiyat alanlarda olduğu anlaşılmaktır.

Tablo 4. Barış Değerine İlişkin Ortaokul Öğrencilerinin Eşleştirmeleri

\begin{tabular}{llllll}
\hline 5.sınıf & f & 6.sınıf & f & 7.sınıf & f \\
\hline Mustafa Kemal Atatürk & 14 & Hz. Muhammed & 9 & Mustafa Kemal Atatürk & 20 \\
Şerife Bacı & 4 & Mustafa Kemal Atatürk & 3 & Hz. Muhammed & 2 \\
Ömer Halisdemir & 3 & Kanuni Sultan Süleyman & 2 & I.Murat & 1 \\
Mehmet Akif Ersoy & 2 & Fatih Sultan Mehmet & 2 & \\
Arif Nihat Asya & 2 & Mehmet Akif Ersoy & 2 & \\
Fatih Sultan Mehmet & 1 & Metehan & 1 & \\
Thomas Edison & 1 & & & \\
Erdem Halit Cengiz & 1 & & & \\
Gumball & 1 & & & \\
Kristina Ancez & 1 & & & \\
Pepe & 1 & & 19 & \\
Toplam & 30 & & & \\
\hline
\end{tabular}


Tablo 4 incelendiğinde barış değerine ilişkin 5.sınıf öğrencilerinin 11; 6.sınıf öğrencilerinin 6 ve 7.sınıf öğrencilerinin ise 3 tarihi kahraman belirttiği görülmektedir. Ayrıca öğrenciler yabancı tarihi kahramanları da belirtmişlerdir. 5.sınıf öğrencileri barış değeri ile "Mustafa Kemal Atatürk" (f=14), "Şerife Bacı" (f=4) ve “Ömer Halisdemir “ $(\mathrm{f}=3)$; 6.sinıf öğrencileri "Hz. Muhammed" (f=9) ve "Mustafa Kemal Atatürk" (f=3); 7.sınıf öğrencileri ise "Mustafa Kemal Atatürk”ü ( $\mathrm{f}=20)$ ilişkilendirmişlerdir. Her düzey öğrenci grubunun ortak olarak en çok üzerinde durduğu tarihi kahramanın "Mustafa Kemal Atatürk" olduğu görülmektedir. Buna ek olarak 6.ve 7.sınıfların ortak tarihi kahraman olarak “Mustafa Kemal Atatürk” ile “Hz. Muhammed” üzerinde durmaktadırlar. 5.ve 6.sınıf öğrencilerinin ise ortak olarak üzerinde durdukları diğer tarihi kahramanların "Mehmet Akif Ersoy" ve "Fatih Sultan Mehmet" olduğu görülmektedir. Öğrencilerin barış değerini genel olarak siyasi, askeri, dini ve edebiyat alanlarındaki tarihi kahramanlarla ilişkilendirdikleri söylenebilir. Ayrıca 5.sınıf öğrencilerinden biri de araştırmanın yapıldığı şehirde önemli bir yerel tarihi kahraman olan "Şerife Bacı"yı barış değeri ile ilişkilendirmiştir.

Tablo 5. Bilimsellik Değerine İlişkin Ortaokul Öğrencilerinin Eşleştirmeleri

\begin{tabular}{llllll}
\hline 5.sınıf & f & 6.sınıf & f & 7.sınıf & f \\
\hline Aziz Sancar & 10 & Thomas Edison & 6 & İbn-i Sina & 6 \\
Thomas Edison & 6 & Mimar Sinan & 4 & Harezmi & 4 \\
Albert Einstein & 4 & Albert Einstein & 4 & Albert Einstein & 3 \\
Graham Bell & 3 & Hz. Muhammed & 2 & El Biruni & 3 \\
Mustafa Kemal Atatürk & 2 & Cahit Arf & 1 & Thomas Edison & 2 \\
Vecihi Hürkuş & 2 & Graham Bell & 1 & Aziz Sancar & 2 \\
Mimar Sinan & 1 & Mustafa Kemal Atatürk & 1 & Recep Tayyip Erdoğan & 1 \\
Halil İnancık & 1 & & & Piri Reis & 1 \\
İbni Sin-a & 1 & & & Mimar Sinan & 1 \\
Seyit Onbaşı & 1 & & \multirow{2}{*}{ Mustafa Kemal Atatürk } & & 1 \\
Toplam & 31 & & & 23 \\
\hline
\end{tabular}

Öğrencilerin bilimsellik değerine ilişkin görüşleri incelendiğinde 5.sınıf öğrencilerinin 10;6.sınıf öğrencilerinin 7 ve 7.sınıf öğrencilerinin 10 farklı tarihi kahraman belirttiği görülmektedir. Ayrıca öğrencilerin araştırmanın bu değerine ilişkin olarak belirttikleri tarihi kahramanlarında genel anlamda farklılaştığı söylenebilir. 5.sınıf öğrencileri bilimsellik değerini en fazla "Aziz Sancar" ( $\mathrm{f}=10)$, Thomas Edison $(\mathrm{f}=6)$ ve Albert Einstein ( $\mathrm{f}=4)$; 6.sinıf öğrencileri "Thomas Edison” ( $\mathrm{f}=6)$, "Mimar Sinan" (f=4) ve "Albert Einstein" $(f=4)$; 7.sınıf öğrencileri ise "İbn-i Sina” (f=6) ve "Harezmi” yi (f=4) ilişkilendirmişlerdir. 5., 6. ve 7.sınıf öğrencilerinin üzerinde 
durdukları ortak değerlerin bu değer için farklılaştığı söylenebilir. Ancak ortak belirttikleri tarihi kahramanlar da mevcuttur. 5.ve 6.sınıf öğrencileri “Thomas Edison”, “Albert Einstein”, "Mustafa Kemal Atatürk” ve "Graham Bell”; 5. ve 7.sınıf öğrencileri “Aziz Sancar", “Thomas Edison”, “Albert Einstein” ve "İbn-i Sina”; 6. ve 7.sinif öğrencileri “Thomas Edison", "Mimar Sinan”, “Albert Einstein” ve "Mustafa Kemal Atatürk” gibi tarihi kahramanlar olduğu görülmektedir. Öğrenciler bilimsellik değerini daha çok bilim insanları ile ilişkilendirmektedirler. Ancak öğrenciler bu değeri "Seyit Onbaş1”, "Hz. Muhammed" ve "Recep Tayyip Erdoğan” gibi askeri, dini ve siyasi alanlardaki tarihi kahramanlarla da ilişkilendirdikleri görülmektedir. Bu durum öğrencilerin bilimsellik değerinin sadece bilim insanları ile ilgili olarak düşünmediklerini göstermektedir. Diğer alanlardaki tarihi kahramanlar ile de bu değeri ilişkilendirmişlerdir.

Tablo 6. Çalışkanlık Değerine İlişkin Ortaokul Öğrencilerinin Eşleştirmeleri

\begin{tabular}{llllll}
\hline 5.sınıf & f & 6.sınıf & f & 7.sınıf & f \\
\hline Mustafa Kemal Atatürk & 9 & Mustafa Kemal Atatürk & 8 & Mustafa Kemal Atatürk & 9 \\
Albert Einstein & 8 & Kaşgarlı Mahmut & 3 & Albert Einstein & 5 \\
Thomas Edison & 6 & Mimar Sinan & 2 & Fatih Sultan Mehmet & 3 \\
Aziz Sancar & 1 & Hz. Muhammed & 1 & El Harezmî & 2 \\
Mehmet Akif Ersoy & 1 & Albert Einstein & 1 & Piri Reis & 2 \\
Leanorda Da Vinci & 1 & Fatih Sultan Mehmet & 1 & Recep Tayyip Erdoğan & 1 \\
Mimar Sinan & 1 & Nikola Tesla & 1 & Aziz Sancar & 1 \\
Amir Khan & 1 & Mehmet Akif Ersoy & 1 & Ali Kuşçu & 1 \\
Şerife Bacı & 1 & Öğretmen & 1 & & \\
Şeyit Onbaşı & 1 & & & & \\
Lionel Messi & 1 & & & & \\
Toplam & 31 & & 19 & & \\
\hline
\end{tabular}

Tablo 6 incelendiğinde çalışkanlık değerine ilişkin 5.sınıf öğrencileri 11; 6.sınıf öğrencileri 9; 7.sınıf öğrencileri ise 8 farklı tarihi kahraman belirtmişlerdir. 5.sınıf öğrencileri çalışkanlık değerini en fazla sırasıyla "Mustafa Kemal Atatürk” ( $f=9)$, "Albert Einstein" (f=8) ve "Thomas Edison" (f=6); 6.sınıf öğrencileri "Mustafa Kemal Atatürk" (f=8) ve "Kaşgarlı Mahmut" (f=3); 7.sınıf öğrencileri "Mustafa Kemal Atatürk” (f=9), “Albert Einstein” ( $f=5$ ) ve "Fatih Sultan Mehmet” ( $f=3$ ) gibi tarihi kahramanlarla ilişkilendirmişlerdir. Öğrencilerin en çok üzerinde durdukları tarihi kahramanın "Mustafa Kemal Atatürk" olduğu görülmektedir. Buna ek olarak öğrencilerin ortak olarak belirttikleri diğer tarihi kahraman ise "Albert Einstein"dır. 5.ve 6.sınıf öğrencilerinin ortak belirttikleri tarihi kahramanlar "Mehmet Akif Ersoy" ve "Mimar Sinan"dır. 5.ve 7.sınıf öğrencilerinin ortak belirttikleri tarihi kahraman "Aziz 
Sancar"dır. 6.ve 7.sınıf öğrencilerinin ortak olarak belirttikleri tarihi kahraman "Fatih Sultan Mehmet”tir. Öğrenciler bu değeri genel olarak askeri, siyasi ve bilim alanlarında çalışan tarihi kahramanlarla ilişkilendirmişlerdir. Ayrıca din, edebiyat, sinema, spor gibi alanlardan tarihi kahramanlar da belirtmişlerdir. 5.sınıf öğrencileri "Şerife Bacı"yı çalışkanlık değeri ile de ilişkilendirmişılerdir. 6.sınıf düzeyindeki bir öğrencinin de çalışkanlık değerini öğretmenlik mesleği ile ilişkilendirmesi oldukça dikkat çekicidir.

Tablo 7. Dayanışma Değerine İlişkin Ortaokul Öğrencilerinin Eşleştirmeleri

\begin{tabular}{llllll}
\hline 5.sınıf & f & 6.sınıf & f & 7.sınıf & f \\
\hline Mustafa Kemal Atatürk & 13 & Mustafa Kemal Atatürk & 10 & Recep Tayyip Erdoğan & 8 \\
Hz. Yusuf & 3 & Şerife Bacı & 2 & Hz. Muhammed & 7 \\
Kaya Giray & 2 & Hz. Hatice & 2 & Dede Korkut & 2 \\
Tahsin Babaş & 2 & Hz. Muhammed & 1 & Hz. Ömer & 2 \\
Enes Batur & 2 & Hz. Yakup & 1 & Piri Reis & 2 \\
Recep Tayyip Erdoğan & 1 & Hz. Ömer & 1 & IV. Murat & 1 \\
Volkan Demirel & 1 & Hz. Ayşe & 1 & Ömer Halisdemir & 1 \\
Şerife Bacı & 1 & Seyit Onbaşı & 1 & Metehan & 1 \\
Nevin Yanıt & 1 & & & & \\
Yunus Emre & 1 & & & & \\
Amir Khan & 1 & & & & \\
Aziz Sancar & 1 & & & & \\
Peter Pan & 1 & & 19 & & \\
Toplam & 31 & & & & \\
\hline
\end{tabular}

Dayanışma değeri ile ilgili 5.sınıf öğrencileri 13; 6.sınıf öğrencileri 8 ve 7.sınıf öğrencileri 8 farklı tarihi kahraman belirtmişlerdir. 5.sınıf öğrencilerinin bu değere ilişkin en çok üzerinde durduğu tarihi kahraman "Mustafa Kemal Atatürk" ( $f=13)$; 6.sınıf öğrencilerinin en çok üzerinde durduğu tarihi kahraman "Mustafa Kemal Atatürk" ( $\mathrm{f}=10)$ ve 7.sınıf öğrencilerinin en çok üzerinde durduğu tarihi kahraman “Recep Tayyip Erdoğan”dır (f=8). 5. ve 6.sınıf öğrencileri ortak olarak "Şerife Bacı”yı; 6. ve 7.sınıf öğrencileri "Hz. Muhammed”i belirtmişlerdir. Öğrenciler genel olarak dayanışma değerini askeri, siyasi, dini ve edebiyat alanlarındaki tarihi kahramanlarla ilişkilendirmişlerdir. Ancak 5.sınıf öğrencileri sosyal medya (Kaya Giray ve Enes Batur), spor (Volkan Demirel ve Nevin Yanıt), bilim (Aziz Sancar), sinema (Amir Khan) ve çizgi film-kitap (Peter Pan) gibi alanlardan da tarihi kahramanlar belirtmişlerdir. Ayrıca 5.sınıf öğrencilerinin diğer bazı değerlerde olduğu gibi dayanışma değeri ile de "Şerife Bacı”yı ilişkilendirdikleri görülmektedir. Buna ilaveten 5.sınıf öğrencilerinden birisi Kastamonu ilinin belediye başkanı "Tahsin Babaş"1 da tarihi kahraman olarak ilişkilendirmiştir.

Tablo 8. Duyarlılık Değerine İlişkin Ortaokul Öğrencilerinin Eşleştirmeleri 


\begin{tabular}{|c|c|c|c|c|c|}
\hline 5.sinuf & f & 6.sinif & f & 7.sinıf & f \\
\hline Hz. Âdem & 4 & Mustafa Kemal Atatürk & 7 & Hz. Muhammed & 9 \\
\hline Mustafa Kemal Atatürk & 4 & Hz. Muhammed & 3 & Mimar Sinan & 3 \\
\hline Recep Tayyip Erdoğan & 4 & Hz. Eyüp & 3 & Mustafa Kemal Atatürk & 2 \\
\hline Hz. Muhammed & 2 & Fatih Sultan Mehmet & 2 & İsmet İnönü & 2 \\
\hline Ömer Halisdemir & 2 & Hz. Hatice & 1 & Şerife Bacı & 2 \\
\hline Orkun Işıtmak & 2 & Hz. Âdem & 1 & Yavuz Sultan Selim & 2 \\
\hline Enes Batur & 2 & Hz. Ali & 1 & Recep Tayyip Erdoğan & 1 \\
\hline Şerife Bacı & 2 & Thomas Edison & 1 & Ömer Seyfettin & 1 \\
\hline Kanuni Sultan Süleyman & 1 & & & Mevlana & 1 \\
\hline Vecihi Hürküş & 1 & & & Hz. Âdem & 1 \\
\hline Mehmet Akif Ersoy & 1 & & & & \\
\hline İbrahim Tatlıses & 1 & & & & \\
\hline Ghulam Siyah & 1 & & & & \\
\hline Barış Manço & 1 & & & & \\
\hline Duygu Köseoğlu & 1 & & & & \\
\hline Thomas Edison & 1 & & & & \\
\hline Oğuz Atay & 1 & & & & \\
\hline Toplam & 31 & & 19 & & 24 \\
\hline
\end{tabular}

Tablo 8 incelendiğinde duyarlılık değeri ile ilgili 5.sınıf öğrencileri 17; 6.sınıf öğrencileri 8; 7.sınıf öğrencileri 10 farklı tarihi kahraman belirtmişlerdir. Duyarlılık değeri ile ilgili en fazla sırasıyla 5.sınıf öğrencileri en fazla "Hz. Âdem” (f=4), "Recep Tayyip Erdoğan" (f=4) ve "Hz. Muhammed"i (f=4); 6.sınıf öğrencileri "Mustafa Kemal Atatürk"ü ve 7.sınıf öğrencileri "Hz. Muhammed”i (f=9) belirtmişlerdir. 5.ve 6.sınıf öğrencileri ortak olarak "Mustafa Kemal Atatürk", ve "Hz. Muhammed"; 5.ve 7.sinıf öğrencileri "Mustafa Kemal Atatürk”, "Hz. Muhammed”, “Recep Tayyip Erdoğan” ve “Şerife Bacı"; 6.ve 7.sınıf öğrencileri "Mustafa Kemal Atatürk” e "Hz. Muhammed” gibi tarihi kahramanlardır. Öğrencilerin genel olarak duyarlılık değerini dini, askeri, siyasi, edebiyat, bilim gibi alanlardaki tarihi kahramanlarla ilişkilendirdikleri görülmektedir. Buna ek olarak 5.sınıf öğrencileri duyarlılık değerini sosyal medya (Orkun Işıtmak, Enes Batur ve Duygu Köseoğlu), müzik (İbrahim Tatlıses ve Barış Manço) ve sinema (Ghulam Siyah-film karakteri) gibi farklı alanlarda bazıları hala yaşayan kişilerle ilişkilendirmişlerdir. 5. ve 7.sınıf öğrencileri duyarlılık değerini yerel bir tarihi kahraman olan "Şerife Bacı" ile ilişkilendirmişlerdir.

Tablo 9. Dürüstlük Değerine İlişkin Ortaokul Öğrencilerinin Eşleştirmeleri

\begin{tabular}{llllll}
\hline 5.sınıf & f & 6.sınıf & f & 7.sınıf & f \\
\hline Mustafa Kemal Atatürk & 12 & Hz. Muhammed & 12 & Hz. Muhammed & 8 \\
Hz. Muhammed & 6 & Mustafa Kemal Atatürk & 4 & Mustafa Kemal Atatürk & 4 \\
Kaya Giray & 2 & Mehmet Akif Ersoy & 3 & Hz. Mevlana & 3 \\
Mehmet Akif Ersoy & 1 & & & Hz. Ebubekir & 2 \\
Kanunu Sultan Süleyman & 1 & & Hz. Âdem & 2 \\
Sultan Mesut & 1 & & Ömer Halisdemir & 2 \\
Hz. Ömer & 1 & & Recep Tayyip Erdoğan & 1
\end{tabular}




$\begin{array}{ll}\text { Seyit Onbaşı } & 1 \\ \text { Sultan 4. Murat } & 1 \\ \text { Ahmet Şah Mesud } & 1 \\ \text { Hz. Ali } & 1 \\ \text { Turgut Ekim } & 1 \\ \text { Baturay } & 1 \\ \text { Şerife Bac1 } & 1 \\ \text { Toplam } & 3\end{array}$

Dürüstlük değeri ile ilgili 5.sınıf öğrencileri 14; 6.sınıf öğrencileri 3 ve 7.sınıf öğrencileri 9 farklı tarihi kahraman belirtmişlerdir. Dürüstlük değeri ile ilgili 5.sınıf öğrencilerinin en çok üzerinde durdukları tarihi kahramanlar "Mustafa Kemal Atatürk" $(f=12)$ ve "Hz. Muhammed" ( $f=6) ; 6$.sınıf öğrencilerinin "Hz. Muhammed" (f=12); 7.sınıf öğrencilerinin “Hz. Muhammed" ( $\mathrm{f}=8)$ ve "Mustafa Kemal Atatürk”tür (f=4). 5. ve 6.sınıf öğrencilerinin ortak olarak belirttikleri tarihi kahramanlar "Mustafa Kemal Atatürk" ve "Hz. Muhammed"; 5. ve 7.sınıf öğrencilerinin "Mustafa Kemal Atatürk” ve “Hz. Muhammed"; 6. ve 7.sınıf öğrencileri "Mustafa Kemal Atatürk" ve "Hz. Muhammed"dir. 5.,6. ve 7.sınıf öğrencilerin ortak olarak üzerinde durdukları tarihi kahramanların aynı tarihi kahramanlar olduğu görülmektedir. Öğrencilerin belirttikleri tarihi kahramanlar genellikle siyaset, askeri, din ve edebiyat alanlarındadır. 5.sinıf öğrencileri sosyal medya fenomenlerini (Kaya Giray, Turgut Ekim ve Baturay) ve Afganistan için önemli bir ismi de (gazeteci-Ahmet Şah Mesud) duyarlılık değeri ile ilişkilendirmişlerdir. Ayrıca 5.sınıf öğrencileri yerel bir tarihi kadın kahraman olan “Şerife Bacı”yı da dürüstlük değeri ile ilişkilendirmişlerdir. 7.sınıf öğrencilerinden bazıları ise "Ömer Halisdemir"i dürüstlük değeri ile ilişkilendirmiştir.

Tablo 10. Estetik Değerine İlişkin Ortaokul Öğrencilerinin Eşleștirmeleri

\begin{tabular}{llllll}
\hline 5.sınıf & f & 6.sınıf & F & 7.sınıf & f \\
\hline Mimar Sinan & 6 & Mimar Sinan & 5 & Mimar Sinan & 17 \\
Başak Karahan & 4 & Zübeyde Hanım & 4 & Mustafa Kemal Atatürk & 2 \\
Fatih Sultan Mehmet & 3 & Mustafa Kemal Atatürk & 4 & Ajda Pekkan & 2 \\
Danla Bilic & 3 & Bülent Ersoy & 2 & Hz. Mevlana & 1 \\
Elizabeth & 3 & Hz. Ali & 2 & Kanuni Sultan Süleyman & 1 \\
Thomas Edison & 2 & Ajda Pekkan & 1 & İbn-i Sina & 1 \\
Ronaldo & 2 & Hz. Ömer & 1 & & \\
Mustafa Kemal Atatürk & 1 & & & \\
İrem Derici & 1 & & & \\
İbn-i Sina & 1 & & & \\
Merve Özkaynak & 1 & & & & \\
Duygu Özaslan & 1 & & &
\end{tabular}


Estetik değeri ile ilgili 5.sınıf öğrencileri 15; 6.sınıf öğrencileri 7 ve $7 . \sin ı f$ öğrencileri ise 6 farklı tarihi kahraman belirtmişlerdir. Bu değere ilişkin her üç sınıf düzeyine ait öğrencilerin de "Mimar Sinan” üzerinde durdukları görülmektedir. 5.sınıf öğrencileri estetik değerini daha çok "Mimar Sinan" ( $f=6)$ ve "Başak Karahan" ( $f=4)$; 6.sınıf öğrencileri "Mimar Sinan” (f=5), "Zübeyde Hanım” (f=4) ve "Mustafa Kemal Atatürk" (f=4); 7.sınıf öğrencileri ise "Mimar Sinan"1 (f=17) tarihi kahramanlar ile ilişkilendirmişlerdir. 5.ve 6.sınıf öğrencilerinin ortak olarak belirttikleri tarihi kahramanlar "Mustafa Kemal Atatürk"; 5.ve 7.sınıf öğrencileri "Mustafa Kemal Atatürk" ve "İbn-i Sina"; 6.ve 7.sınıf öğrencileri ise "Mustafa Kemal Atatürk" ve "Ajda Pekkan"dır. Öğrenciler estetik değerini genel olarak siyaset, askeri, din, bilim, spor, müzik ve sinema gibi alanlardaki tarihi kahramanlar ile ilişkilendirmişlerdir. Ayrıca 5.sınıf öğrencileri estetik değerini araştırmanın yapıldığı ilin yerel kadın kahramanı olan "Şerife Bac1" ile de ilişkilendirmişlerdir.

Tablo 11. Eşitlik Değerine İlişkin Ortaokul Öğrencilerinin Eşleştirmeleri

\begin{tabular}{llllll}
\hline 5.sınıf & f & 6.sınıf & f & 7.sınıf & f \\
\hline Mustafa Kemal Atatürk & 9 & Hz. Muhammed & 7 & Mustafa Kemal Atatürk & 8 \\
Hz. Muhammed & 2 & Mustafa Kemal Atatürk & 5 & Fatih Sultan Mehmet & 7 \\
Adalet Bakanı & 2 & Fatih Sultan Mehmet & 2 & Hz. Ömer & 4 \\
Duygu Köseoğlu & 2 & Hz. Davut & 2 & Hz. Muhammed & 3 \\
Fatih Sultan Mehmet & 2 & Hz. Ebubekir & 1 & Sultan Abdülmecit & 1 \\
Aleyna Tilki & 2 & Hz. Ömer & 1 & Oğuz Kağan & 1 \\
Thomas Edison & 1 & Abbasiler & 1 & & \\
Recep Tayyip Erdoğan & 1 & & & & \\
Sercan İpekçioğlu & 1 & & & & \\
Mevlana & 1 & & & & \\
Tahsin Babaş & 1 & & & & \\
Başak Karahan & 1 & & & & \\
Yavuz Sultan Selim & 1 & & & & \\
Meryem Can & 1 & & & \\
Hz. İbrahim & 1 & & & \\
Mehmet Akif Ersoy & 1 & & & \\
Toplam & 31 & & & & \\
\hline
\end{tabular}

Tablo 11 incelendiğinde eşitlik değeri ile ilgili 5.sınıf öğrencileri 16; 6.sınıf öğrencileri 7; 7.sınıf öğrencileri ise 6 farklı tarihi kahraman belirtmişlerdir. 5.sınıf öğrencilerinin eşitlik değeri ile ilgili en fazla üzerinde durdukları tarihi kahramanlar sırasıyla "Mustafa Kemal Atatürk" (f=9); 6.sınıf öğrencileri "Hz. Muhammed" (f=7) ve "Mustafa Kemal Atatürk" (f=5); 7.sınıf öğrencileri "Mustafa Kemal Atatürk" (f=8) ve "Fatih Sultan Mehmet”tir (f=7). Her üç sınıf düzeyinde de öğrencilerin ortak olarak 
belirttikleri tarihi kahramanlar "Mustafa Kemal Atatürk”, “Hz. Muhammed” ve "Fatih Sultan Mehmet”tir. 5.ve 6.sınıf öğrencilerinin başka ortak olarak belirttikleri tarihi kahraman bulunmamaktadır. 6.ve 7.sınıf öğrencileri ise "Hz. Ömer"i ortak tarihi kahraman olarak belirtmişlerdir. Genel olarak tüm öğrencilerin eşitlik değerini siyaset, askeri, din ve edebiyat alanlarındaki tarihi kahramanlarla ilişkilendirdikleri görülmektedir. Ayrıca öğrenciler eşitlik değeri ile araştırmanın yapıldığı ilin belediye başkanı "Tahsin Babaş"1 da ilişkilendirmişlerdir.

Tablo 12. Özgürlük Değerine İlişkin Ortaokul Öğrencilerinin Eşleştirmeleri

\begin{tabular}{llllll}
\hline 5.sınıf & f & 6.sınıf & F & 7.sınıf & f \\
\hline Mustafa Kemal Atatürk & 15 & Mustafa Kemal Atatürk & 12 & Mustafa Kemal Atatürk & 10 \\
Enes Batur & 2 & Hz. Muhammed & 2 & Hz. Muhammed & 5 \\
Tarkan & 2 & Fatih Sultan Mehmet & 2 & Sabiha Gökçen & 3 \\
Hz. Muhammed & 1 & Vecihi Hürküş & 1 & Fatih Sultan Mehmet & 2 \\
Aziz Sancar & 1 & Hz. Ali & 1 & Timur & 2 \\
Hz. Ebu Talip & 1 & Hz. Zeyd & 1 & Kara Murat & 1 \\
Mehmet Akif Ersoy & 1 & & & Diego Maradona & 1 \\
Seyit Onbaşı & 1 & & & & \\
Fatih Sultan Mehmet & 1 & & & & \\
Danla Bilic & 1 & & & & \\
Barış Manço & 1 & & & & \\
Hazarfen Ahmet Çelebi & 1 & & & \\
İbrahim Tatlıses & 1 & & & \\
Mustafa Ceceli & 1 & & 19 & & \\
Amir Khan & 1 & & & \\
Toplam & 31 & & & & \\
\hline
\end{tabular}

Özgürlük değeri ile ilgili 5.sınıf öğrencileri 15; 6.sınıf öğrencileri 5; 7.sınıf öğrencileri ise 7 farklı tarihi kahramanı ilişkilendirmişlerdir. Özgürlük değerini 5.sınıf öğrencileri sırasıyla en fazla "Mustafa Kemal Atatürk" ( $\mathrm{f}=15)$; 6.sınıf öğrencileri "Mustafa Kemal Atatürk" ( $\mathrm{f}=12)$; 7.sınıf öğrencileri ise "Mustafa Kemal Atatürk" $(\mathrm{f}=10)$ ve "Hz. Muhammed” $(\mathrm{f}=5)$ üzerinde durmaktadırlar. 5. ve 6.sınıf öğrencilerinin ortak olarak belirttikleri tarihi kahramanlar "Mustafa Kemal Atatürk", “Hz. Muhammed" ve "Fatih Sultan Mehmet"; 5. ve 7.sınıf öğrencilerinin ortak olarak belirttikleri tarihi kahramanlar "Mustafa Kemal Atatürk”, “Hz. Muhammed” ve "Fatih Sultan Mehmet”; 6. ve 7.sınıf öğrencilerinin ortak olarak belirttikleri tarihi kahramanlar ise "Mustafa Kemal Atatürk”, “Hz. Muhammed” ve “Fatih Sultan Mehmet”tir. Öğrenciler genel olarak özgürlük değerini siyaset, askeri, din, bilim ve edebiyat alanındaki tarihi kahramanlarla ilişkilendirmişlerdir. $\mathrm{Bu}$ alanların dışında müzik (Tarkan, Barış Manço, İbrahim Tatlıses ve Mustafa Ceceli), sosyal medya (Enes Batur 
ve Danla Bilic), sinema (Amir Khan ve Kara Murat) alanlarında yer alan tarihi kahramanlardan da bahsettikleri görülmektedir.

Tablo 13. Saygı Değerine İlişkin Ortaokul Öğrencilerinin Eşleştirmeleri

\begin{tabular}{llllll}
\hline 5.sınıf & f & 6.sınıf & F & 7.sınıf & f \\
\hline Mustafa Kemal Atatürk & 13 & Hz. Muhammed & 7 & Hz. Muhammed & 8 \\
Mevlana & 4 & Mustafa Kemal Atatürk & 6 & Mustafa Kemal Atatürk & 4 \\
Recep Tayyip Erdoğan & 2 & Hz. Ali & 2 & Mevlana & 4 \\
Mehmet Akif Ersoy & 2 & Hz. Osman & 2 & Kanuni Sultan Süleyman & 3 \\
Hz. Yusuf & 2 & Fatih Sultan Mehmet & 1 & Hz. Yakup & 1 \\
Tahsin Babaş & 1 & Hz. İsa & 1 & Hz. Yunus & 1 \\
Mimar Sinan & 1 & & & Ömer Seyfettin & 1 \\
Enes Batur & 1 & & & Ali Kuşçu & 1 \\
Adem Kılıçcı & 1 & & & Cengizhan & 1 \\
Danla Biliç & 1 & & & & \\
Çağla Demirel & 1 & & & & \\
Başak Karahan & 1 & & & & \\
Birce Akalay & 1 & & 19 & & \\
Toplam & 31 & & & & \\
\hline
\end{tabular}

Tablo 13 incelendiğinde saygı değerini 5.sınıf öğrencileri 13; 6.sınıf öğrencileri 6 ve 7.sınıf öğrencileri 9 farklı tarihi kahraman ile ilişkilendirmişlerdir. 5.sınıf öğrencileri saygı değerini en fazla sırasıyla "Mustafa Kemal Atatürk" (f=13) ve "Mevlana" (f=4); 6.sınıf öğrencileri "Hz. Muhammed" (f=7) ve "Mustafa Kemal Atatürk" (f=6); 7.sınıf öğrencileri "Hz. Muhammed” ( $f=8)$, "Mustafa Kemal Atatürk" $(f=4)$ ve "Mevlana" ( $f=4)$ ile ilişkilendirmişlerdir. Her üç sınıf düzeyinin de ortak olarak üzerinde durduğu tarihi kahramanın "Hz. Muhammed” ve "Mustafa Kemal Atatürk" olduğu görülmektedir. Öğrencilerin belirtikleri bu tarihi kahramanların siyaset, askeri, din, edebiyat, bilim, spor, sinema ve sosyal medya alanlarından kişiler olduğu görülmektedir.

Tablo 14. Sevgi Değerine İlişkin Ortaokul Öğrencilerinin Eşleş̧irmeleri

\begin{tabular}{llllll}
\hline 5.sınıf & f & 6.sınıf & f & 7.sınıf & f \\
\hline Mustafa Kemal Atatürk & 13 & Hz. Muhammed & 10 & Hz. Muhammed & 13 \\
Enes Batur & 3 & Mustafa Kemal Atatürk & 5 & Hz. Yusuf & 4 \\
Sultan Osman & 2 & Mimar Sinan & 2 & Hz. Ali & 2 \\
Mevlana & 2 & Hz. Âdem & 1 & Hz. Yunus & 1 \\
Meryem Can & 2 & Şerife Bacı & 1 & Fatih Sultan Mehmet & 1 \\
Hz. Muhammed & 1 & & & Özdemir Asaf & 1 \\
Esila Biltekin & 1 & & Yavuz Sultan Selim & 1 \\
Merve Özbey & 1 & & Mehmet Akif Ersoy & 1 \\
Atilla İlhan & 1 & & & & \\
Mimar Sinan & 1 & & & & \\
Thomas Edison & 1 & & & & \\
Seyit Onbaşı & 1 & & &
\end{tabular}


Sevgi değeri ile ilgili 5.sınıf öğrencileri 15; 6.sınıf öğrencileri 5 ve 7.sınıf öğrencileri 8 farklı tarihi kahraman belirtmişlerdir. 5.sınıf öğrencileri sevgi değerini en fazla sırasıyla "Mustafa Kemal Atatürk" (f=13) ve "Enes Batur" (f=3); 6.sinıf öğrencileri "Hz. Muhammed" ( $\mathrm{f}=10)$ ve "Mustafa Kemal Atatürk" (f=5); 7.sinif öğrencileri "Hz. Muhammed” (f=13) ve "Hz. Yusuf” (f=4) ile ilişkilendirmişlerdir. 5.ve 6.sınıf öğrencilerinin sevgi değeri ile ilgili ortak üzerinde durduğu tarihi kahramanlar "Mustafa Kemal Atatürk" ve "Hz. Muhammed"; 5.ve 7.sınıf öğrencilerinin "Hz. Muhammed"; 6.ve 7.sınıf öğrencilerinin ise "Hz. Muhammed"dir. Öğrencilerin sevgi değeri ile ilişkilendirdikleri tarihi kahramanların genellikle siyasi, askeri, dini, edebiyat ve bilim alanlarında olduğu görülmektedir. Ayrıca 6.sınıf öğrencileri yeril bir tarihi kahraman olan “Şerife Bacı”yı da sevgi değeri ile ilişkilendirdikleri görülmektedir.

Tablo 15. Sorumluluk Değerine İlişkin Ortaokul Öğrencilerinin Eşleștirmeleri

\begin{tabular}{llllll}
\hline 5.sını & f & 6.sınıf & f & 7.sınıf & f \\
\hline Mustafa Kemal Atatürk & 9 & Mustafa Kemal Atatürk & 9 & Ömer Halisdemir & 6 \\
Cüneyt Arkın & 3 & Hz. Muhammed & 4 & Mustafa Kemal Atatürk & 5 \\
Recep Tayyip Erdoğan & 2 & Şerife Bacı & 2 & Hz. Muhammed & 3 \\
Öğretmen & 2 & Fatih Sultan Mehmet & 1 & Mimar Sinan & 3 \\
Thomas Edison & 2 & Hz. Ebubekir & 1 & Fatih Sultan Mehmet & 2 \\
Mimar Sinan & 2 & Hz. Fatma & 1 & Kazım Karabekir & 1 \\
Albert Einstein & 1 & Anne & 1 & Atilla & 1 \\
Mevlana & 1 & & & Ertuğrul & 1 \\
Esila Biltekin & 1 & & Hz. İsa & 1 \\
Başak Karahan & 1 & & Aziz Sancar & 1 \\
Barış Manço & 1 & & & \\
Hz. Hatice & 1 & & & \\
Mehmet Akif Ersoy & 1 & & & & \\
Şerife Bac1 & 1 & & & & \\
Ronaldo & 1 & & & \\
Gomes & 1 & & & \\
Seyit Onbaş1 & 1 & & & \\
Toplam & 31 & & & \\
\hline
\end{tabular}

Tablo 15 incelendiğinde sorumluluk değerine ilişkin 5.sınıf öğrencilerinin 17 tarihi kahraman; 6.sınıf öğrencilerinin 7 tarihi kahraman; 7.sınıf öğrencilerinin ise 10 farklı tarihi kahraman belirttikleri görülmektedir. Sorumluluk değeri ile ilgili $5 . \sin 1 f$ öğrencileri sırasıyla en fazla "Mustafa Kemal Atatürk" (f=9) ve "Cüneyt Arkın" (f=3); 6.sınıf öğrencileri "Mustafa Kemal Atatürk" (f=4) ve "Hz. Muhammed" (f=4); 7.sinıf öğrencileri ise “Ömer Halisdemir" ( $f=6)$ ve "Mustafa Kemal Atatürk"ü ( $f=5)$ belirtmiştir. Her üç sınıf düzey öğrencilerin ortak olarak üzerinde durduğu tarihi 
kahramanın "Mustafa Kemal Atatürk” olduğu görülmektedir. 5. ve 6.sınıf öğrencileri ortak olarak başka herhangi bir tarihi kahraman belirtmemişlerdir. 6. ve 7.sınıf öğrencilerinin ortak olarak belirttikleri tarihi kahramanların "Hz. Muhammed”, "Şerife Bacı" ve "Fatih Sultan Mehmet” olduğu görülmektedir. Öğrenciler sorumluluk değerini siyaset, askeri, din, bilim, edebiyat, sosyal medya, sinema ve spor gibi alanlardaki tarihi kahramanlarla ilişkilendirmişlerdir. Ancak sorumluluk değerini 5.sınıf öğrencilerinden bazılarının "öğretmen", 6.sınıf öğrencilerinden de birisinin "anne" kavramı ile ilişkilendirmesi bu araştırma için oldukça dikkat çekici bir bulgudur. Öğrencilerin bu değeri doğrudan bir tarihi kahramanla ilişkilendirmek yerine "öğretmen” ve “anne” kavramına yüklenen anlamı göstermesi bakımından önemlidir. 7.sınıf öğrencilerinin “Ömer Halisdemir”i sorumluluk değeri ile ilişkilendirmeleri bu değerin toplumsal açıdan gerekli olduğunu da ortaya koyar niteliktedir.

Tablo 16. Tasarruf Değerine İlişkin Ortaokul Öğrencilerinin Eşleştirmeleri

\begin{tabular}{llllll}
\hline 5.sınıf & f & 6.sınıf & f & 7.sınıf & f \\
\hline Hz. Muhammed & 7 & Hz. Muhammed & 8 & Hz. Muhammed & 14 \\
Lewis Carroll & 4 & Thomas Edison & 4 & Thomas Edison & 2 \\
Tahsin Babaş & 3 & Mustafa Kemal Atatürk & 3 & Hz. Yusuf & 1 \\
Thomas Edison & 3 & Hz. Ali & 2 & Hz. Ali & 1 \\
Mustafa Kemal Atatürk & 3 & Hz. Ayşe & 1 & Mimar Sinan & 1 \\
Mimar Sinan & 2 & Şerife Bacı & 1 & Glyasettin Keyhüsrev & 1 \\
Fatih Sultan Mehmet & 2 & & & Fatih Sultan Mehmet & 1 \\
Babaannem & 2 & & & Ertuğrul Gazi & 1 \\
Hz. Hatice & 2 & & & Berat Albayrak & 1 \\
Hz. Âdem & 1 & & & & 1 \\
Hz. Ömer & 1 & & \multirow{2}{*}{ Ȩobanoğlu } & \\
Albert Einstein & 1 & & & & 24 \\
Toplam & 31 & & & \\
\hline
\end{tabular}

Tasarruf değerini 5.sınıf öğrencileri 12; 6.sınıf öğrencileri 6; 7.sınıf öğrencileri ise 10 farklı tarihi kahraman ile ilişkilendirmişlerdir. 5.sınıf öğrencileri tasarruf değerini en fazla sirasıyla "Hz. Muhammed" ( $\mathrm{f}=7$ ) ve "Lewis Caroll” ( $\mathrm{f}=4)$; 6.sınıf öğrencileri "Hz. Muhammed" (f=8) ve "Thomas Edison" ( $\mathrm{f}=4)$; 7.sınıf öğrencileri ise "Hz. Muhammed" ( $\mathrm{f}=14)$ ve "Thomas Edison" ( $\mathrm{f}=2)$ ile ilişkilendirmişlerdir. Her üç sınıf düzeyindeki öğrencilerin ortak olarak üzerinde durdukları tarihi kahramanların "Hz. Muhammed” ve “Thomas Edison” olduğu görülmektedir. 5. ve 6.sınıf öğrencilerinin tasarruf değeri ile ilgili ortak olarak belirttikleri tarihi kahraman "Mustafa Kemal Atatürk”tür. 6. ve 7.sınıf öğrencilerinin tasarruf değeri ile ilgili ortak olarak belirttikleri tarihi kahraman ise "Hz. Ali”dir. Tasarruf değeri ile ilgili öğrenciler genel olarak din, 
bilim ve siyaset alanlarından tarihi kahramanları ilişkilendirmişlerdir. 5. ve 7.sınıf öğrencilerinden bazılarının günümüzün siyaset ve sosyal medya alanında tanınmış insanlarını da (Berat Albayrak ve Enes Çobanoğlu) tarihi kahraman olarak belirttikleri görülmektedir. 5.sınıflardan bazı öğrencilerin de tasarruf değerini "babaanem" kavramı ile ilişkilendirmeleri dikkat çekmektedir.

Tablo 17. Vatanseverlik Değerine İlişkin Ortaokul Öğrencilerinin Eşleştirmeleri

\begin{tabular}{llllll}
\hline 5.sınıf & f & 6.sınıf & f & 7.sınıf & f \\
\hline Mustafa Kemal Atatürk & 16 & Mustafa Kemal Atatürk & 9 & Ömer Halisdemir & 11 \\
Şerife Bacı & 5 & Fatih Sultan Mehmet & 6 & Mustafa Kemal Atatürk & 5 \\
Ömer Halisdemir & 4 & Hz. Muhammed & 2 & Fatih Sultan Mehmet & 2 \\
Ertuğrul Gazi & 2 & Seyit Onbaşı & 2 & Hz. Ömer & 1 \\
Recep Tayyip Erdoğan & 1 & & & Alaadin Keykubat & 1 \\
Mehmet Akif Ersoy & 1 & & & IV.Murat & 1 \\
Seyit Onbaşı & 1 & & & İbn-i Sina & 1 \\
Tahsin Babaş & 1 & & & & 1 \\
Micheal Jackson Tayyip Erdoğan & 19 & & 1 \\
Toplam & 1 & & \multicolumn{2}{c}{} \\
\hline
\end{tabular}

Tablo 17 incelendiğinde vatanseverlik değerini 5.sınıf öğrencileri 9; 6.sınıf öğrencileri 4; 7.sınıf öğrencileri ise 8 farklı tarihi kahraman ile ilişkilendirmişlerdir. Vatanseverlik değerini 5.sınıf öğrencileri en fazla sırasıyla "Mustafa Kemal Atatürk" $(\mathrm{f}=16)$, "Şerife Bacı" ( $\mathrm{f}=5$ ) ve "Ömer Halisdemir" ( $\mathrm{f}=4)$; 6.sınıf öğrencileri "Mustafa Kemal Atatürk" (f=9) ve "Fatih Sultan Mehmet" (f=6) ve 7.sınıf öğrencileri “Ömer Halisdemir" ( $\mathrm{f}=11$ ) ve "Mustafa Kemal Atatürk" ile ilişkilendirmişlerdir. 5. ve 6.sınıf öğrencilerinin vatanseverlik değerini ortak olarak ilişkilendirdikleri tarihi kahraman "Seyit Onbaşı"dır. 5. ve 7.sınıf öğrencilerinin vatanseverlik değerini ortak olarak ilişkilendirdikleri tarihi kahramanlar "Ömer Halisdemir" ve "Recep Tayyip Erdoğan"dır. 6. ve 7.sınıf öğrencilerinin vatanseverlik değerini ortak olarak ilişkilendirdikleri tarihi kahraman ise "Fatih Sultan Mehmet”tir. Her üç sınıf düzeyi öğrencileri vatanseverlik değerini ortak olarak "Mustafa Kemal Atatürk" ile ilişkilendirmişlerdir. 5. ve 7.sınıf öğrencileri günümüzün siyaset alanında tanınmış siyasetçilerini de (Recep Tayyip Erdoğan) vatanseverlik değeri ile ilişkilendirmişlerdir. "Ömer Halisdemir"in ise 7.sınıf öğrencileri tarafından vatanseverlik değeri ile ilişkilendirilmesi öğrencilerin yakın tarihi önemsediklerini göstermesi bakımından anlamlıdır. Öğrenciler vatanseverlik değerini genel olarak dini, askeri ve siyasi alanlardaki tarihi kahramanlarla ilişkilendirmişlerdir.

Tablo 18.Yardımseverlik Değerine İlişkin Ortaokul Öğrencilerinin Eşleştirmeleri 


\begin{tabular}{llllll}
\hline 5.sınıf & f & 6.sınıf & f & 7.sınıf & f \\
\hline Mustafa Kemal Atatürk & 8 & Hz. Muhammed & 8 & Hz. Muhammed & 6 \\
Şerife Baci & 6 & Mustafa Kemal Atatürk & 7 & Mustafa Kemal Atatürk & 4 \\
Hz. Muhammed & 5 & Hz. Ebubekir & 3 & Yunus Emre & 4 \\
Victor Hugo & 3 & Hz. Ali & 1 & Kanuni Sultan Süleyman & 2 \\
Baturay Anar & 2 & & & Mehmet Akif Ersoy & 2 \\
Tahsin Babaş & 2 & & & Pele & 1 \\
Cristian Ronaldo & 1 & & Hz. Yusuf & 1 \\
Edison & 1 & & Hz. Addem & 1 \\
Orkun Işııtmak & 1 & & Hz. Yakup & 1 \\
Mevlana & 1 & & Mevlana & 1 \\
Süper Man & 1 & & Kara Murat & 1 \\
Toplam & 31 & & 19 & & 24 \\
\hline
\end{tabular}

Yardımseverlik değerini 5.sınıf öğrencileri 11; 6.sınıf öğrencileri 4 ve $7 . \sin ı f$ öğrencileri ise 11 farklı tarihi kahraman ile ilişkilendirmişlerdir. 5.sınıf öğrencileri yardımseverlik değerini en fazla sırasıyla "Mustafa Kemal Atatürk" ( $f=8)$, "Şerife Bacı" $(f=6)$ ve "Hz. Muhammed" (f=5); 6.sinif öğrencileri "Hz. Muhammed” (f=8) ve "Mustafa Kemal Atatürk" (f=7); 7.sınıf öğrencileri "Hz. Muhammed" (f=6), "Mustafa Kemal Atatürk" (f=4) ve "Yunus Emre" (f=4) gibi tarihi kahramanlarla ilişkilendirmişlerdir. Her üç sınıf düzeyine ait öğrenciler yardımseverlik değerini ortak olarak "Hz. Muhammed" ve "Mustafa Kemal Atatürk" ile ilişkilendirmişlerdir. 5. ve 7.sınıf öğrencilerinin yardımseverlik değerini ortak olarak ilişkilendirdikleri diğer tarihi kahraman "Mevlana”dır. Yardımseverlik değerine ilişkin öğrencilerin genellikle siyasi, askeri ve dini tarihi kahramanlarla ilişkilendirme yaptıkları görülmektedir. Ancak edebiyat, spor, bilim, sosyal medya ve film kahramanları da öğrenciler tarafından belirtilen diğer alanlardır. Ayrıca 5.sınıf öğrencilerinin "Şerife Bacı" gibi yerel bir tarihi kahramanı ve araştırmanın yapıldığı ilin belediye başkanı "Tahsin Babaş"ı bu değer ile de ilişkilendirdikleri görülmektedir.

\section{Tartışma ve Sonuç}

Bağımsızlık, çalışkanlık ve özgürlük değerlerinde en çok tekrarlanan tarihi kahramanın "Mustafa Kemal Atatürk" olduğu görülmekteyken, aile birliğine önem verme ve tasarruf değerlerinde "Hz. Muhammed (s.a.v.)”in olduğu görülmektedir. Sayg1, sevgi, sorumluluk, yardımseverlik ve eşitlik değerlerinde 5. sınıfta en çok tekrarlanan tarihi kahraman "Mustafa Kemal Atatürk" iken 6. ve 7.sınıflarda "Hz. Muhammed (s.a.v.)"in olduğu görülmektedir. Estetik değerinde en çok tekrarlanan tarihi kahraman “Mimar Sinan”dır. Barış değerinde 5.sınıf öğrencileri “Hz. Muhammed 
(s.a.v.)”i ilişkilendirirken, 6 ve 7. sınıf öğrencileri “Mustafa Kemal Atatürk”ü tarihi kahraman olarak belirtmektedirler. Dürüstlük değerinde 5 ve 6 . sınıflar "Mustafa Kemal Atatürk”ü tarihi kahraman olarak gösterirken, 7.sınıflar “Hz. Muhammed (s.a.v.)”i göstermiştir. Dayanışma değerinde 5 ve 6.sınıflar “Mustafa Kemal Atatürk”ü tarihi kahraman olarak gösterirken, 7.sınıflar "Recep Tayyip Erdoğan"1 tarihi kahraman olarak göstermektedir. Vatanseverlik değerinde 5. ve 6.sınıflar "Mustafa Kemal Atatürk” ü tarihi kahraman olarak gösterirken, 7.sınıflar “Ömer Halis Demir”i göstermektedirler. Karagözoğlu (2018) çalışmasında sosyal bilgiler dersinde vatanseverlik değerinin kazandırılmasında Ayşe Hanım, Nazife Hanım, Şerife Hanım, Tayyar Rahmiye Hanım, Halide Edip Adıvar, Elif Bacı, Kılavuz Hatice Hanım, Gördesli Makbule Hanım, Nene Hatun, Halime Çavuş, Asker Saime Hanım, Fatma Seher Hanım ve Tarsuslu Kara Fatma Hanım gibi tarihi kadın şahsiyetlerden yararlanılabileceğini belirtmektedir. Tokcan ve Kolyiğit (2017)'in çalışmasında ise öğrencilerin en fazla tanıdıkları önemli kadın şahsiyetlerin Sabiha Gökçen, Tansu Çiller ve Halide Edip Adıvar olduğu görülmektedir. Bu araştırmada da ortaokul öğrencilerinin değerleri kadın tarihi kahramanlarla ilişsilendirdikleri görülmektedir. Duyarlılık değerinde 5.sınıflar tarihi kahraman olarak en fazla “Hz. Adem”i gösterirken, 6.sınıflar “Mustafa Kemal Atatürk”ü ve 7.sınıflar ise “Hz. Muhammed (s.a.v.)”i tarihi kahraman olarak göstermişlerdir. Bilimsellik değerinde 5.sınıflar tarihi kahraman olarak en çok “Aziz Sancar”1 gösterirken, 6.sınıflar "Thomas Edison”u, 7.sınıflar ise "İbn-i Sina”y1 tarihi kahraman olarak göstermişlerdir. Adalet değerinde 5.sınıflar ve 6.sınıflar en fazla “Mustafa Kemal Atatürk”ü, 7.sınıflar ise “Hz. Ömer”i örnek göstermişlerdir. Elban (2018)'nın çalışmasında tarihi kahramanlardan ahlak ve değerler eğitiminde yararlanıldığı belirtilmektedir. Bu durum bu araştırmadan elde edilen bulguları destekler niteliktedir.

Değerlere dair örnek olarak verilen tarihi kahramanların içinde en fazla tekrarlanan “Mustafa Kemal Atatürk”tür. Bu durum Yazıcı ve Aslan (2011) ile Faiz ve Yazıcı (2018)'nın çalışmalarıyla benzerlik göstermektedir. Gibbon (2002), bütün toplumlarda devletin kurucularının önde gelen kahramanlar olarak kabul edildiğini; bu yüzden en fazla rol model gösterilen kahramanlar arasında yer aldığını belirtir. Değerler eğitiminde kahramanlardan yararlanmada en çok Atatürk'ün yer alması devletin 
kurucusu olmasının yanı sıra eğitim sistemimizin üzerine kurulu olduğu anayasal ve ideolojik yapısı ile MEB Temel Kanunu'nda belirtilen eğitimsel amaçlarla da uyumluluk göstermektedir. Bu sonucun çıkmasında Mustafa Kemal Atatürk’ün hem iyi bir asker hem de iyi bir devlet adamı olmasından kaynaklanabileceği düşünülebilir. Türkler defalarca vatan toprakları için savaşlar yapmış, bağımsızlığına düşkün, çalışkan insanlardır. Bunun dışında en çok örnek gösterilen tarihi kahramanlar arasında "Hz. Muhammed (s.a.v.)” ve “Hz. Ömer”in gösterilmesi Türkiye'nin dindarlık düzeyinin birçok ülkeden daha yüksek olması (Çarkoğlu ve Kalaycıoğlu, 2009; Çarkoğlu ve Toprak, 2000) ve öğrenciler tarafından dini kahramanların üst düzey tanımlanması durumları ile ilişkilendirilebilir. Öğrenciler “Ömer Halis Demir”i de değerlerle ilişkilendirmişlerdir. Bunun sebebi ise Ömer Halis Demir’in 15 Temmuz'da yaptığı kahramanlıktan öğrencilerin etkilenmesi olarak düşünülebilir. Öğrenciler sosyal fenomenleri de değerlerle ilişkilendirmişlerdir. Bu durum sosyal medyanın öğrenciler üzerinde ne kadar etkili olduğunu göstermektedir. Ayrıca öğrencilerin çalışmanın yapıldığı ilde önemli bir tarihi kahraman olan "Şerife Bacı”yı ve çalışmanın yapıldı̆̆ı ilin belediye başkanı "Tahsin Babaş”ı da değerlerle ilişkilendirmeleri dikkat çekici bir durumdur. Bunun yanında çeşitli evrensel tarihi kahramanları da programdaki farklı değerlerle ilişkilendirmişlerdir. Öğrencilerin tarihi kahramanları askeri, siyasi, din, bilim, edebiyat gibi farklı alanlardaki tarihi kahramanlarla ilişkilendirdikleri de görülmektedir. Öğrencilerin tarihi kahraman algısının literatürde de belirtildiği gibi zamansız olarak algılamaları tarihi kahraman kavramını doğru anladıklarını göstermektedir. “Aziz Sancar”, “Recep Tayyip Erdoğan”, “Ömer Halis Demir” ve bazı tanınmış sosyal medya kullanıcıları ile spor ve müzik dünyasından bazı isimleri belirtmeleri kahramanları henüz yaşayan kişilerden de tercih ettiklerini ortaya koymaktadır. Dolayısıyla öğrencilerin kahramanları sadece geçmişte yaşayan kişiler olarak algılamadıkları anlaşılmaktadır.

\section{Öneriler}

$\mathrm{Bu}$ çalışma ortaokul öğrencileriyle yapılmıştır. Farklı örneklem grubuyla da benzeri çalışmalar yapılabilir. Öğretmenler, öğretmen adayları ve ilkokul, lise öğrencileri gibi... Çalışma, nitel yöntemle yapılıış bir çalışmadır. Nicel desenli ya da karma desenli 
çalışmalar da yapılabilir. 2018 programına yönelik düzenlenen ders kitabında verilen tarihi kahramanların incelenebilir.

\section{Makalenin Bilimdeki Konumu}

Türkçe ve Sosyal Bilimler Eğitimi/Sosyal Bilgiler Eğitimi

\section{Makalenin Bilimdeki Özgünlüğü}

Literatürde değer öğretimine dair çeşitli çalışmalar mevcuttur. Rol model alarak öğrenme yaklaşımı değer eğitiminde diğer yaklaşımlardan daha çok işlevseldir. Bundan dolayı ortaokul öğrencilerinin değerleri ilişkilendirdiği tarihi kahramanları tespit etmek ve bu tespit sonucunda bu kahramanlara yer vermek değer eğitimini etkili kılacaktır.

\section{Kaynakça}

Akbaş, O. (2004). Türk milli eğitim sisteminin duyuşsal amaçlarının ilköğretim II. kademedeki gerçekleşme derecesinin değerlendirilmesi. (Yayımlanmamış doktora tezi), Ankara Gazi Üniversitesi Eğitim Bilimleri Enstitüsü, Ankara.

Akbaş, O. (2009). İlköğretim okullarında görevli branş öğretmenlerinin değer öğretimi yaparken kullandıkları etkinlikler: 2004 ve 2007 yıllarına ilişkin bir karşılaştırma. Kastamonu Ĕ̆itim Dergisi, 17(2), 403-414.

Aslan, M. (2009). Değerler eğitiminde kahramanlardan yararlanma. (Yayımlanmamış yüksek lisans tezi). Gaziosmanpaşa Enstitüsü Sosyal Bilimler Enstitüsü, Tokat.

Beldă̆, A. (2012). Illköğretim yedinci sınıf Sosyal Bilgiler dersindeki değerlerin kazanılma düzeyinin çeşitli değişkenler açısından incelenmesi (Erzurum ili örneği). (Yayımlanmamış doktora tezi). Atatürk Üniversitesi Eğitim Bilimleri Enstitüsü, Erzurum.

Bandura, A. (1977). Social learning theory. NJ: Prentice Hall.

Bohning, G, Hodson, A., Foote, T., McGee, C., \& Young, B. (1998). Identifying and examining adolescents’ moral values. Urban Education, 33 (2), 264- 280.

Chandler, M. K. (2005). The effect of a character education program on elementary students’ prosocial competence. (Unpublished masters thesis), Lynn University, Florida, USA.

Coombs-Richardson, R., \& Homer T. (2005). A Comparison of values rankings for selected American and Australian teachers. Journal of Research in International Education, 4 (3), 263- 277. 
Creswell, J. W. (2014). Research design: Qualitative, quantitative, and mixed methods approaches. California: Sage.

Çarkoğlu, A., \& Kalaycığlu, E. (2009) Türkiye’de dindarlık: uluslararası bir karşılaştırma. İstanbul: Sabancı Üniversitesi.

Çarkoğlu, A., \& Toprak, B. (2000). Türkiye'de din, toplum ve siyaset. İstanbul: Türkiye Ekonomik ve Sosyal Etüdler Vakfi.

Çengelci, T. (2010). İlköğretim beşinci sınıf Sosyal Bilgiler dersinde değerler eğitiminin gerçekleştirilmesine ilişkin bir durum çalışması. (Yayımlanmamış doktora tezi), Anadolu Üniversitesi Eğitim Bilimleri Enstitüsü, Eskişehir.

Demircioğlu, İ. H. ve Tokdemir, M. A. (2008). Değerlerin oluşturulma sürecinde tarih eğitimi: Amaç, işlev ve içerik. Değerler Ĕ̆itimi Dergisi, 6 (15), 69-88.

Doğanay, A. (2006). Değerler eğitimi. C. Öztürk (Ed.), Hayat bilgisi ve sosyal bilgiler öğretimi (s. 223-256) içinde. Ankara: PegemA Yayıncılık.

Dönmez, C. (2006). Değerler eğitiminde kahramanların kullanımına bir örnek: Mustafa Kemal Atatürk. Gazi Eğitim Fakültesi Dergisi, 26, 113-133.

Ekiz, D. (2013). Bilimsel araştırma yöntemleri. Ankara: An1 Yayıncılık.

Elban, M. (2018). Tarih düşüncesinde ve eğitiminde kahramanların/büyük adamların rolü. Motif Akademi Halk Bilimi Dergisi, 11 (22), 98-116.

Evrim, İ. ve Kafadar, O. (2004). İlköğretim sosyal bilgiler programının ve ders kitaplarının ulusal ve evrensel değerler yönünden içerik çözümlemesi. Türk Eğitim Bilimleri Dergisi, 2 (3), 293-304.

Faiz, M. \& Yazıc1, K. (2018) Social studies teacher candidates' views on the use of historical heroes in values education, International Journal Of Eurasia Social Sciences, 9 (33), 1897-1918.

Fidan, N. K. (2009). Öğretmen adaylarının değer öğretimine ilişkin görüşleri. Kuramsal Eğitim Bilim Dergisi, 2 (2), 1-18.

Fraenkel, Jack R. (1968). Teaching strategies for value education in social studies: A theoretical position. Erişim adresi: www.eric.ed.gov. ERIC Document No: ED 44320.

Gedik, E. G. (2010). Sinıf öğretmenlerinin dĕger yönelimlerinin ve öğrencilere aktarmak istedikleri değerlerin incelenmesi. (Yayınlanmamış yüksek lisans tezi). Zonguldak Karaelmas Üniversitesi Sosyal Bilimler Enstitüsü, Zonguldak. 
Gibbon, P. H. (2002). Heroes for our age: How heroes can elevate students' lives. Erişim adresi: https://files.eric.ed.gov/fulltext/EJ962694.pdf

Hall, D. (2003). Childhood Heroes. 18.04.2018 tarihinde http://citeseerx.ist.psu.edu/viewdoc/download?doi=10.1.1.87.9561\&rep=rep1\&ty pe $=$ pdf adresinden erişilmiştir.

Karagözoğlu, N. (2018). Sosyal bilgiler dersinde vatanseverlik değerinin kazandırılmasında kadın kahramanların yaşam öykülerinin kullanılması. International Journal of Field Education, 4 (2), 97-110.

K1lıç-Şahin, H. (2010). İlköğretim okullarında Sosyal Bilgiler dersini yürüten 4. ve 5. Sınıf öğretmenlerinin sosyal bilgiler dersi öğretim programında yer alan değerlerin kazandırılmasına ilişkin görüşleri. (Yayımlanmamış yüksek lisans tezi). Gazi Üniversitesi Eğitim Bilimleri Enstitüsü, Ankara.

Kymlicka, W. (2004). Çağdaş siyaset felsefesine giriş, İstanbul: İstanbul Üniversitesi Yayınları.

Lakshimi, C. (2009). Value education: an Indian perspective on the need for moral education in a time of rapid social change, Journal of College \& Character, 10 (3), 1-7.

Leblanch, B. F. (2007). Teacher's perception, training, and implementation of character Education: Implications for Staff Development. (Unpublished doctoral thesis), George Mason University. Fairfax, USA.

Ledford, A. T. (2005). A study of teachers' efficacy for teaching character education. (Unpublished doctoral thesis), Regent University School of Education, VA, USA.

Lewis, J. G. (2007). The Impact on Teacher Practice When Character Education is Integrated Into Curriculum. (Unpublished doctoral thesis), Boston College, USA.

Moore, A. L. (2005). A case study of how an elementary school aged student receives and responds to character education. (Unpublished doctoral thesis), University of Wyoming, USA.

Miethe, T. (2001). The validity and reliability of value measurements. The Journal of Psychology, 119 (5), 441-453.

Owens, V. (2005). Values disparity and academic achievement among ugandan adolescents. Journal of Beliefs and Values, 26 (3), 311-315. 
Revell, L. (2002). Children's responses to character education. Educational Studies. 4 (28), 421-431.

Sanchez, T. R. (1998). Using stories about heroes to teach values. Erişim adresi: www.ericfacility.net/ericdigests/ed424190.html.

Sarı, E. (2005). Öğretmen adaylarının değer tercihleri: Giresun Eğitim Fakültesi örneği. Değerler Ĕ̈itimi Dergisi, 3 (10), 73-88.

Silfver, M. (2007). Gender differences in value priorities, guilt, and shame among Finnish and Peruvian adolescents. Sex Roles, 56 (9-10), 601-609.

Singh, M., \& Lu, M. (2003). Exploring the function of heroes and heroines in children's literature. Erişim adresi: From www.eric.ed.gov (ERIC Document Reproduction No: ED 477609).

Tokcan, H. \& Kolyiğit, E. (2017). Türk tarihinde yer alan önemli kadın şahsiyetler hakkında öğrenci bilgi düzeyleri. Uluslararası Sosyal Bilgilerde Yeni Yaklaşımlar Dergisi, 1, 3141.

Tahiroğlu, M. (2011). Illköğretim 4. Sınıf Sosyal Bilgiler dersinde doğa sevgisi, temizlik ve sağlıklı olma dĕgerlerinin öğretimi ve değerlere ilişkin ögrenci tutumlarının belirlenmesi. (Yayımlanmamış doktora tezi), Gazi Üniversitesi Eğitim Bilimleri Enstitüsü, Ankara.

Thornberg, R. (2008). The lack of professional knowledge in values education. Teaching and Teacher Education, 24 (7), 1791-1798.

Tay, B. (2009). Prospective teachers' views concerning the values to teach in the course of social sciences. Social and Behavioral Sciences, 1, 1187-1191.

Titus, D. N. (1994). Values education in American secondary schools. Erişim adresi: https://eric.ed.gov/?id=ED381423

Tokdemir, M. A. (2007). Tarih öğretmenlerinin değerler ve değer eğitimi hakkındaki görüşleri. (Yayımlanmamış yüksek lisans tezi), Karadeniz Teknik Üniversitesi Sosyal Bilimler Enstitüsü, Trabzon.

Veugelers, W. (2000). Different ways of teaching values. Educational Review, 25 (1), 37-46.

Veugelers, W. \& Kat, E. (2003). Moral task of the teacher according to students, parents and teachers. Educational Research and Evaluation, 9 (1), 75-91. 
Ulusoy, K. (2007). Lise tarih programında yer alan geleneksel ve demokratik dĕgerlere yönelik öğrenci tutumlarının ve görüşlerinin çeşitli değişkenler açısından değerlendirilmesi (Yayınlanmamış doktora tezi). Gazi Üniversitesi Eğitim Bilimleri Enstitüsü, Ankara.

Willemse, M., Lunenberg, M. \& Korthagen, F. (2005). Values in education: a challenge for teacher educators. Teaching and Teacher Education, 21, 205- 217.

Yazıcı, K. (2006). Değerler eğitimine genel bir bakış. Türklük Bilimi Araştırmaları, 19, 499-522.

Yazic1, S. \& Aslan, M. (2011). Using Heroes as role models in values education: A comparison between social studies textbooks and prospective teachers' choice of hero or heroines. Educational Sciences: Theory and Practice, 11 (4), 2184-2188.

Yıldırım, A. \& Şimşek, H. (2016). Sosyal bilimlerde nitel araştırma yöntemleri. Ankara: Seçkin Yayınc1lı

Yıldırım, K. (2009). Values education experiences of Turkish class teachers. A phenomological approach. Eurasian Journal of Educational Research, 35, 165184.

Yiğittir, S. ve Kaymakc1, S. (2012). Sosyal Bilgiler Dersi Öğretim Programı uygulama kılavuzunda yer alan etkinliklerin değer eğitimi yaklaşımları açısından incelenmesi, Ahi Evran Üniversitesi Kırşehir Eğitim Fakültesi Dergisi, 13(2), 4973.

\section{Summary \\ Problem Statement}

Values education has become an important phenomenon in many countries in the last century. Therefore, how values can be gained has been questioned in almost every country today. Together with the increasing interest in values education, theorists and researchers have developed various methods and strategies related to values education. The model of learning through observation, one of these methods and strategies, constitutes the main element of being a role modern and it has long been accepted as an important method in values education. When the process of teaching and learning is considered, teachers are the primary people whom the students see as role models. Teachers are the heroes in the daily lives of young learners in particular (Yazıcı \& Aslan, 2011). In values education, affective and behavioral dimensions are more prominent than the cognitive dimension. That teachers reflect this on their behavior while they are teaching values is of great importance in shaping students' behaviors (Titus, 1994). 
Although teachers are good role models, it is also known that children find other heroes later on as well (Gibbon, 2002). With the approach of using heroes in educational systems, problems such as social life disruptions, violence and political instability can be overcome (Yazıcı \& Aslan, 2011). The fact that the heroes are historical people will contribute to the affective and cognitive development of the students. The lives of historical heroes are a means of transferring values (Demircioğlu and Tokdemir, 2008). Historical heroes are also a function of being a role model for individuals. Individuals can acquire various learning outcomes by taking historical heroes as role models. According to Bandura (1977), individuals learn by imitating models and observing their behavior. To him, the fact that people of high status in societies are the most imitated models can be considered as a result of learning by observing and taking them as role models. In Bandura's social learning theory, individuals can learn new cognitive skills and behaviors, strengthen or extinguish what they have learned, learn how to use the environment and objects and how to demonstrate emotional reactions, and provide motivation by observing models. It can be claimed that this situation is also valid for the transfer of values. In this study, secondary school students were asked to relate the relevant historical heroes to the values listed in the Social Studies Lesson Curriculum. Values education can be made more effective by finding out the heroes that have impact on the students.

\section{Method}

The study has been designed in a case study research model. It has utilized this model because the $5^{\text {th }}, 6^{\text {th }}$ and $7^{\text {th }}$ grade students' perceptions about how they relate values to the historical heroes have are discussed. The study group consisted of 31 in fifth grade, 19 students in sixth grade and 24 students in seventh grade. That is, a total of 74 secondary school students participated in this study. While the study group was selected, convenience sampling method which is one of the non-random sampling techniques was used. The data obtained within the scope of the research were analyzed by descriptive analysis method, which is often preferred in qualitative research.

\section{Results and Discussion}

Mustafa Kemal Ataturk appeared as the most-repeatedly-mentioned historical hero for the values of independence, industriousness and freedom. On the other hand, Prophet Mohammad was the most repeated name for the values of giving importance to the unity of family and savings. As for the values of respect, love, responsibility, benevolence and equality, Mustafa Kemal Ataturk was the most-repeated name by the $5^{\text {th }}$ grades and Prophet Mohammad was written by the $6^{\text {th }}$ and $7^{\text {th }}$ grades. Architect (Mimar) Sinan was the most-repeatedly mentioned historical figure for the value of aesthetics. For the value of peace, Prophet 
Mohammad was written by the $5^{\text {th }}$ grades and Mustafa Kemal Ataturk was indicated by the $6^{\text {th }}$ and $7^{\text {th }}$ grades. As for the value of honesty, Mustafa Kemal Ataturk was mentioned as the relevant historical hero by the $5^{\text {th }}$ and $6^{\text {th }}$ grades and Prophet Mohammad was written by the $7^{\text {th }}$ grades. While the $5^{\text {th }}$ and $6^{\text {th }}$ grades referred to Mustafa Kemal Ataturk, the $7^{\text {th }}$ grade students referred to Recep Tayyip Erdogan as the historical hero for the value of solidarity. For the value of patriotism, Mustafa Kemal Ataturk was mentioned by the $5^{\text {th }}$ and $6^{\text {th }}$ grades and Omer Halis Demir was written by the $7^{\text {th }}$ grade. The fifth grade students wrote Prophet Adam, the sixth grade students wrote Mustafa Kemal Ataturk and the seventh grade students wrote Prophet Mohammad as the historical heroes for the value of sensitivity. For the value of being scientific, Aziz Sancar was mentioned by the $5^{\text {th }}$ grade, Thomas Edison was listed by the $6^{\text {th }}$ grade and Ibn Sina (Avicenna) was written by the $7^{\text {th }}$ grade students. Mustafa Kemal Ataturk was listed by the $5^{\text {th }}$ and $6^{\text {th }}$ grades and Omar (the second Muslim caliph) was mentioned by the $7^{\text {th }}$ grade students as historical heroes for the value of justice.

Mustafa Kemal Ataturk is the most frequently repeated historical hero given as an example related to the values. This finding is in line with that of Yazıcı \& Aslan (2011) and Faiz \& Yazıc1 (2018). Gibbon (2002) states that as the founders of the state are considered to be the leading heroes in all societies, they are among heroes taken as role models. Moreover, this is also in accord with the constitutional and ideological structures of Turkish education system as well as with the educational objectives defined in the Fundamental Law of the Ministry of National Education. It can be considered that this result appeared here since Mustafa Kemal Ataturk was regarded as a good soldier and a good statesman. Turks have repeatedly taken parts in wars for their homeland and are industrious people who are fond of their independence. Therefore, this result was somehow foreseeable.

In addition, religious figures such as Prophet Mohammad and Omar (the second Muslim caliph) were listed among the most frequently mentioned historical heroes. This can be related to the level of piety in Turkey, which is considered higher than in many other countries (Çarkoğlu \& Kalaycıŏglu, 2009; Çarkoğlu \& Toprak, 2000). The students also mentioned Ömer Halis Demir as an example of the historical heroes. This can be due to the fact that the students might have been affected by what he had done on July $15^{\text {th }}$. The students also gave examples of some bloggers. This shows how effective social media can be in their lives. 